\title{
Gastric Sensory and Motor Functions and Energy Intake in Health and Obesity-Therapeutic Implications
}

\author{
Lizeth Cifuentes ${ }^{1}$, Michael Camilleri ${ }^{2}$ and Andres Acosta ${ }^{2, *}$ \\ 1 Precision Medicine for Obesity Program and Clinical Enteric Neuroscience Translational and Epidemiological \\ Research Program, Department of Medicine, Mayo Clinic, Rochester, MN 55905, USA; \\ Cifuentes.adriana@mayo.edu \\ 2 Division of Gastroenterology and Hepatology, Mayo Clinic, 200 First Street SW, Rochester, MN 55905, USA; \\ Camilleri.michael@mayo.edu \\ * Correspondence: acosta.andres@mayo.edu; Tel.: +1-507-266-6931
}

check for updates

Citation: Cifuentes, L.; Camilleri, M.; Acosta, A. Gastric Sensory and Motor Functions and Energy Intake in Health and Obesity-Therapeutic Implications. Nutrients 2021, 13, 1158. https://doi.org/10.3390/nu13041158

Academic Editor:

Christine Feinle-Bisset

Received: 23 January 2021

Accepted: 26 March 2021

Published: 1 April 2021

Publisher's Note: MDPI stays neutral with regard to jurisdictional claims in published maps and institutional affiliations.

Copyright: (c) 2021 by the authors. Licensee MDPI, Basel, Switzerland. This article is an open access article distributed under the terms and conditions of the Creative Commons Attribution (CC BY) license (https:// creativecommons.org/licenses/by/ $4.0 /)$.

\begin{abstract}
Sensory and motor functions of the stomach, including gastric emptying and accommodation, have significant effects on energy consumption and appetite. Obesity is characterized by energy imbalance; altered gastric functions, such as rapid gastric emptying and large fasting gastric volume in obesity, may result in increased food intake prior to reaching usual fullness and increased appetite. Thus, many different interventions for obesity, including different diets, anti-obesity medications, bariatric endoscopy, and surgery, alter gastric functions and gastrointestinal motility. In this review, we focus on the role of the gastric and intestinal functions in food intake, pathophysiology of obesity, and obesity management.
\end{abstract}

Keywords: food intake; gastric emptying; gastric accommodation; satiation; satiety

\section{Introduction}

Obesity is a chronic and complex disease marked by a body mass index (BMI) greater than $30 \mathrm{~kg} / \mathrm{m}^{2}$ and affects almost 600 million adults worldwide [1]. Obesity complexity is related to a multi-factorial imbalance between energy intake and energy expenditure, leading to excess energy storage [2]. The mechanism of moving from fasting to foodseeking and food intake is closely controlled by homeostatic and hedonic signals that combine to influence eating behavior. This homeostatic regulation involves peripheral organs and the nervous system and is referred to as the gut-brain-adipose axis [3,4]. The behavioral background is essential for explaining normal and disorderly feeding, particularly, excessive overeating, contributing to the obesity crisis. However, the central neural mechanism integrating food reward and gastric sensory and enteroendocrine signals has been adequately reviewed elsewhere [5-9].

In the gut, the stomach plays a significant role in regulating hunger, satiation, and satiety [10]. The stomach can sense mechanical forces, control the rate at which calories reach the duodenum, and trigger gastrointestinal peptide secretion. These functions play an essential role in providing short-term and long-term signals to control food intake [10,11]. Alterations in gastrointestinal motility observed in patients with obesity may contribute to weight gain [12-14]. Therefore, interventions designed to modify gastrointestinal motility or have a secondary impact on gastric physiology are components of obesity treatment.

The present paper is a narrative review based on publications focused on physiological measurements of gastric functions and their potential contribution to obesity. In particular, to understand the effects on gastric sensory and motor functions of different obesity treatments, we considered data from case-control, cross-sectional, cohort, and randomized controlled clinical trials. We excluded data measured by paracetamol drug absorption due to the potential confounding factors. Similarly, we have assessed lifestyle interventions, such as low-calorie diets, on objective measurements of gastric emptying 
and compared them to subjective scales for appetite. Our assessment included Food and Drug Administration (FDA) approved medications in use for diabetes or obesity. We also examined two meta-analyses that appraised effects of bariatric and surgical procedures on gastric emptying, and we updated the literature search to December 2020.

In this review, we examined the relationship between gastric sensory and motor functions with food intake. We focused first on the regulation of these functions by endocrine and neural pathways on health and discuss the abnormalities observed in obesity. We considered the significance of these functions in the pathophysiology of obesity, the contradictory findings on this topic, and have discussed the contribution of variability in these measurements in interpretation of the data. Finally, we have addressed obesity treatment strategies that target the gastric sensory and motor functions.

\section{Regulation of Gastric Emptying and Gastric Accommodation}

The stomach accommodates, triturates, and empties food into the duodenum through coordinated motor activities within proximal and distal regions. The proximal region's critical function is to store food, while the distal region generates the mechanical forces for trituration to a particle size $<2 \mathrm{~mm}$ that facilitates emptying and digestion. Neural and endocrine control mechanisms mediate these functions. For example, the proximal stomach exhibits low sustained contractions responsible for the basal tone. After food reaches the stomach, the vagus nerve coordinates the change in fundic compliance (also called accommodation), which allows the stomach to form a reservoir with only a limited rise in intragastric pressure [15], thereby facilitating food ingestion [16].

The ingestion of a meal is linked to coordinated contractile events in the stomach, especially in the antrum. This series of contractile activities leads to the grinding of solids and the beginning of solid emptying. Moreover, there is a positive relationship between the rate of antral contractions and the emptying of solids $[17,18]$.

When food reaches the stomach, the body and antrum create phasic contractions that are activated by the pacemaker apparatus in the wall of the stomach consisting of interstitial cells of Cajal (ICC) and fibroblast-like cells expressing platelet-derived growth factor-alpha (PDGFR $\alpha$ ) receptors [19,20].

Phasic contractions or peristaltic waves originate at the greater curve opposite to the incisura angularis and propagate toward the pylorus. The pylorus relaxes while the contractions increase in frequency and intensity in response to neurotransmitters from enteric neurons released in response to gastric distention [21]. As the pyloric sphincter remains closed, the gastric material is propelled backward where the antral contractions grind and mix the contents, resulting in a viscous pulverized material before being emptied into the duodenum [22]. The stomach empties digestible solids when the particle size has been reduced to about $2 \mathrm{~mm}$ or less [23].

Thus, stomach emptying of digestible solids only starts after a lag phase required for trituration; emptying is facilitated by an increase in fundus tone, and the pyloric sphincter opens intermittently as peristaltic waves originating in the body continue to pass into the pylorus. Coordinated antro-pyloric contractions propel chyme into the duodenum [18], which relaxes and allows the well-coordinated chyme distribution. These activities are under the control of neuronal circuits and gastrointestinal hormones (Figure A1 in Appendix A). The enteroendocrine function is closely linked to gastrointestinal motor activity, which determines when and for how long the nutrients interact with enteroendocrine cells. Moreover, the release of hormones, primarily in response to nutrients, provides feedback regulation of gastric emptying.

\subsection{Neural Regulation}

Interactions between the syncytium formed by smooth muscle, ICCs and PDGFR $\alpha$ cells, the enteric system, and the central nervous system (CNS) involve multiple neurotransmitters [24]. Acetylcholine is the primary excitatory neurotransmitter, and nitric oxide and vasoactive intestinal peptides act as inhibitory neurotransmitters [25,26]. In- 
terneurons integrate information from sensory (e.g., response to distension by food) and motor enteric neurons. The CNS provides extrinsic neural input from parasympathetic and sympathetic pathways. The sympathetic nervous system exerts a direct inhibitory influence on $\alpha_{1}$-adrenoceptors and an indirect inhibitory effect on $\alpha_{2}$-adrenoceptors. The parasympathetic nervous system exerts both excitatory and inhibitory control through the vagus nerve by activating intrinsic excitatory (e.g., cholinergic) and inhibitory (e.g., nitric oxide, vasoactive intestinal peptide, somatostatin) nerves in the stomach wall [25,27].

The vagus nerves exert both inhibitory and excitatory effects on the stomach [28]. Intraganglionic laminar endings (IGLEs) and intra-muscular arrays (IMAs) serve as sensory end-organs that activate vagal afferents. IGLEs, located between the two smooth muscle layers of the stomach, serve as tension receptors. IMAs, within the smooth muscle layer, function as stretch and length detectors [29]. Smooth muscle tone is also perceived by intrinsic nitrergic nerves and can induce fundic relaxation. The innervation from the extrinsic vagus nerve and the intrinsic nitrergic nerves also control the smooth muscle cells to mediate the postprandial accommodation response [16].

During the filling phase, accommodation maintains low intra-gastric pressure until a critical stretch level is reached and triggers vagal afferents that activate hypothalamic neurons and induce the feeling of fullness and activate tonic contractions of the fundus and peristaltic contractions in the remainder of the stomach [30].

\subsection{Hormonal Regulation}

Hormones are an effective regulatory mechanism for gastric emptying. The spectrum of hormonal actions ranges from "brake" hormones to accelerating hormones. The brake hormones include cholecystokinin (CCK); the products from pre-proglucagon, glucagonlike peptide-1 (GLP-1), glucagon-like peptide-2 (GLP-2), gastric inhibitory polypeptide (GIP), and oxyntomodulin; the polypeptide-fold family proteins peptide tyrosine-tyrosine (PYY) and pancreatic polypeptide (PP); and leptin.

In the gastrointestinal tract, CCK is released from the duodenal and jejunal mucosa by the enteroendocrine I cells in response to nutrients. Lipids, predominantly long-chain fatty acids, and proteins are the most potent stimuli [31]. CCK activates vagal afferents and thereby relaxes the proximal stomach, reduces antral contractility, and activates pyloric tone, slowing gastric emptying. CCK's effects in gastric motility include tone reduction of the proximal stomach, suppressing antral contractions, and stimulating tonic contraction of the pylorus [32]. CCK, infused at rates to mimic postprandial plasma concentrations, slowed gastric emptying of a liquid meal by $30 \%$ and a semisolid meal by $40 \%$ [33,34]. Loxiglumide, a potent and highly specific antagonist of CCK, accelerated the gastric emptying rates of a liquid mixed meal and pure glucose meal by about $40 \%$ [35].

GLP-1 is a posttranslational product of the proglucagon gene, and it is secreted by L cells in the small intestine and colon, particularly in response to glucose and fat in the intestinal lumen [36]. In addition to a glucose-dependent action, GLP-1 can slow gastric emptying and increase postprandial gastric volume to impact satiety [37]. These actions are mediated via vagal afferent pathways and stimulation of inhibitory nitrergic myenteric neurons [38]. Accordingly, the exogenous administration of GLP-1 delays gastric emptying of liquids and solids, whereas the GLP-1 antagonist, exendin-(9-39), has been proven to accelerate gastric emptying of a mixed nutrient meal [39-42] with even an impact on glycemic responses.

Other proglucagon-derived peptides inhibit gastrointestinal motility to a lesser degree than GLP-1 [43]. Previously, GIP was considered as a component of the brake hormones, delaying gastric emptying [44]; however, physiological concentrations of GIP have failed to affect gastric emptying [45,46]. Therefore, it has not been used as a therapeutic target (e.g., in metabolic syndrome or obesity).

PYY is released from enteroendocrine L cells, both in the ileum and colon, in response to meals [47]. Endogenous PYY was associated with a decreased gastric emptying rate [48], and exogenous $\mathrm{PYY}_{3-36}$ resulted in a reduction in food intake without affecting gastric 
emptying [49]. Amylin is co-secreted with insulin from the $\beta$-cells of the pancreas, and it inhibits vagal signaling, slowing gastric emptying and promoting satiety. A decrease in the gastric emptying rate has been replicated with the amylin analog, pramlintide [50].

Leptin is released by the adipocytes around body fat stores and within the gastrointestinal system by the parietal cells of the gastric mucosa [51]. In animal studies, both intraperitoneal and intracerebral administration of leptin decreased the gastric emptying rate. Peripheral administration of leptin increased CCK release and activation of vagal cholinergic receptors, while central administration may affect the dorsal vagal complex $[52,53]$.

Ghrelin is an orexigenic hormone produced by the cells of the gastric oxyntic mucosa and the small intestine [54]. Administration of synthetic ghrelin decreased the autonomic response to gastric distension and accelerated both gastric emptying and small bowel transit $[55,56]$. The infusion of the ghrelin receptor agonists, relamorelin and ulimorelin, resulted in a dose-dependent acceleration of gastric emptying. Relamorelin accelerated gastric emptying up to $17 \%$ from baseline in patients with gastroparesis without inhibiting gastric accommodation in healthy adults [57-59]. Recently, ulimorelin also showed a dose-dependent acceleration of gastric emptying of up to $44 \%$ from baseline in healthy adults [60].

\subsection{Measurement of Gastric Motor Functions}

A variety of tests are available to evaluate gastric motor functions; however, simultaneous assessment of gastric volume, accommodation, and emptying has only been recently reported in healthy adults, not in disease states or in response to pharmacological agents [61]. Gastric volume and accommodation can be invasively measured using an intragastric barostatically-controlled balloon or indirectly using reconstruction of transaxial images acquired with single-photon emission computed tomography (SPECT). Non-invasive imaging techniques (i.e., ultrasound, MRI, and SPECT) allow estimation of gastric volume without evaluating muscle tone [62] (Table 1).

The gold standard for measuring gastric emptying is gamma camera scintigraphy, which is a physiological, non-invasive, and objective assessment of gastric emptying. Scintigraphy comprises a radiolabeled meal, such as with ${ }^{99} \mathrm{~m}$ technetium, with subsequent imaging to assess emptying of solids. In 2008, the consensus statement from the American Neurogastroenterology and Motility Society and the Society of Nuclear Medicine recommended a standardized method with a low-fat, egg-white meal of $240 \mathrm{kcal}$ with imaging at 0-2 and $4 \mathrm{~h}$ after meal ingestion [63]. Camilleri et al. published data on 314 health adults (210 females and 105 males) from an extensively validated protocol that was introduced into practice in 1991; this meal consisted of a $320 \mathrm{kcal}, 30 \%$ fat meal with imaging at the same time points after meal ingestion $[64,65]$. Delayed gastric emptying is classified as $>60 \%$ of the solid meal being retained at $2 \mathrm{~h}$ or more than $10 \%$ of the meal being left after $4 \mathrm{~h}$. On the other hand, $<70 \%$ retention at $30 \mathrm{~min}$ or $<30 \%$ stomach retention at $1 \mathrm{~h}$ is indicative of more rapid gastric emptying [63]. Despite the protocol guidelines, several centers continue to perform sub-optimal studies (e.g., imaging for $2 \mathrm{~h}$ ) that compromises the consistency and usefulness of the research on gastric emptying in disease states, including obesity [66].

Ultrasonography is a widely available bedside approach that quantifies changes in the cross-sectional antral area. Two-dimensional ultrasonography allows inferring gastric emptying and accommodation in various pathologies (e.g., functional dyspepsia, diabetes, gastroesophageal reflux, liver cirrhosis) and correlated antral distension with postprandial satiation in healthy subjects [67-69]. Three-dimensional ultrasonography reproduces the image of the total stomach and shows real-time intragastric meal distribution [70]. The volume changes provide a valid measure of gastric emptying rate in health and disease [71-73]. However, these techniques are difficult to standardize and are operatordependent, or they are compromised by variation in body habitus, particularly when the proximal stomach is covered by the rib cage. 
Table 1. Methods to measure gastric motor functions.

\begin{tabular}{ccc}
\hline Method & Equipment Required & Principle \\
\hline Scintigraphy & $\begin{array}{c}\text { External gamma camera and } \\
\text { isotope-labeled meal }\end{array}$ & $\begin{array}{c}\text { Calculating volume content } \\
\text { after ingestion of a } \\
\text { isotope-labeled meal, with } \\
\text { images obtained with a } \\
\text { gamma camera at baseline 1, } \\
2 \text {, and } 4 \text { h. }\end{array}$ \\
\hline Ultrasonography & Ultrasound scanners & $\begin{array}{c}\text { Measurement of changes in } \\
\text { antral cross-sectional area or } \\
\text { diameter over time. }\end{array}$ \\
\hline
\end{tabular}

Measurement of gastric volume, secretion, emptying,

Magnetic Resonance MRI scanner
and contractions derived from repetitive scans. Gastric meal volume is calculated by taking into account gastric secretion.

\begin{tabular}{|c|c|c|}
\hline Isotope breath test & $\begin{array}{l}\text { Breath collection vials and } \\
\text { stable isotope-labeled meal }\end{array}$ & $\begin{array}{l}\text { Measurement of breath } \\
\text { excretion of }{ }^{13} \mathrm{CO}_{2} \text { after } \\
\text { ingestion with a solid meal. } \\
\text { After ingestion, it is absorbed } \\
\text { in the proximal small } \\
\text { intestine, metabolized by the } \\
\text { liver, and excreted by the } \\
\text { lungs, and results in a rise in } \\
\text { expired }{ }^{13} \mathrm{CO}_{2} \text {. }\end{array}$ \\
\hline Drug Absorption & Plasma levels of paracetamol & $\begin{array}{l}\text { Measurement of plasma } \\
\text { concentrations, assuming that } \\
\text { small intestine intestine } \\
\text { absorption will reflect the } \\
\text { gastric emptying rate. }\end{array}$ \\
\hline $\begin{array}{l}\text { Wireless pressure and } \mathrm{pH} \\
\text { capsule }\end{array}$ & $\begin{array}{l}\text { Intraluminal capsule with } \\
\text { miniaturized strain gauge and } \\
\text { pH measurement. }\end{array}$ & $\begin{array}{c}\text { The simultaneous intragastric } \\
\text { measurement of } \mathrm{pH} \text { and } \\
\text { pressure is used to evaluate } \\
\text { gastric emptying. }\end{array}$ \\
\hline Barostat & $\begin{array}{l}\text { Barostatically-controlled } \\
\text { balloons. }\end{array}$ & $\begin{array}{l}\text { A polyethylene balloon is } \\
\text { inserted via the esophagus, } \\
\text { situated in the gastric fundus } \\
\text { in apposition with the wall, } \\
\text { and distended until an } \\
\text { intrabag volume of } 30 \mathrm{~mL} \text { is } \\
\text { achieved or until respiratory } \\
\text { variation is detected. The } \\
\text { volume is calculated based on } \\
\text { the changes in pressure and } \\
\text { diameter. }\end{array}$ \\
\hline
\end{tabular}

A valid alternative approach is the measurement of breath excretion of ${ }^{13} \mathrm{CO}_{2}$ after ingesting a meal containing a stable isotope such as ${ }^{13} \mathrm{C}$-spirulina or ${ }^{13} \mathrm{C}$-octanoate [74]. The gastric emptying breath test constitutes an indirect, non-radioactive alternative. The subject consumes a meal with the stable isotope, and this results in a rise in expired ${ }^{13} \mathrm{CO}_{2}$ that is measured $[75,76]$.

Paracetamol absorption was proposed as a surrogate method to measure gastric emptying rate, assuming that the passage time of paracetamol through the stomach is identical to that of the meal. The plasma concentration of paracetamol was later commonly used for gastric emptying assessment [74,77]. However even when administered together 
with a solid meal, the paracetamol was released from the solid meal, dissolved in the liquid phase of the gastric content, and generally reflected the emptying of liquid from the stomach rather than the emptying of a solid meal. In general, most disease states are associated with normal absorption of Paris eat a mal, and therefore parameters such as the $0-5$-h area under the curve of plasma paracetamol concentration is not a good reflection of the potential of a disease or pharmacological agent to modify, particularly delay, the gastric emptying of solids from the stomach. There is, moreover, a lack of consideration of pharmacokinetics in the absorption of paracetamol, which shows strong interindividual variability [78-80]. Using plasma levels of paracetamol for gastric emptying can contribute to incorrect conclusions. This is exemplified by the contradictory information regarding the effects of liraglutide on gastric emptying based on paracetamol absorption versus scintigraphic emptying of a mixed solid and liquid meal [81,82].

Nondigestible wireless capsules are recording devices which move through the gastrointestinal tract to detect $\mathrm{pH}$, pressure, and temperature. The simultaneous intragastric measurement of $\mathrm{pH}$ and pressure is used to evaluate gastric emptying [83]. Barostaticallycontrolled balloons can calculate the gastric volume and estimate gastric accommodation. The volume is calculated based on the changes in pressure and diameter [84]. This procedure is the gold standard, but it is an invasive, non-physiologic, uncomfortable technique with relatively low reliability. However, these techniques have not been widely used in relation to obesity.

In order to assess the association between gastric motor functions and gastrointestinal symptoms or appetite sensations, a physiological test, i.e., a nutrient drink test, has been developed [85-87]. The test was initially designed to correlate symptoms of functional dyspepsia with maximum tolerated volume. It traditionally involved the ingestion of a nutrient drink at a constant rate of $30 \mathrm{~mL}$ per minute using a constant-rate perfusion pump. Participants record their sensations at 5-min intervals using a numerical scale from 0 to 5 , with 0 being no symptoms, 3 corresponding to fullness sensation after a typical meal to address the volume to fullness (VTF), and 5 corresponding to the maximum tolerated volume (MTV). Nutrient intake is stopped when subjects reach a score of 5 [85]. Vijayvargiya et al. showed that, in 62 obese adults (92\% females), a higher fasting gastric volume correlated with the calorie intake to reach comfortable fullness at a single meal and the VTF in the nutrient drink test [88].

\section{Gastric Sensory and Motor Functions and Food Intake}

Physiological information and external environmental cues regulate food intake and appetite. The steps in the cycle of food consumption have been determined as hunger, satiation, and satiety [89]. Hunger is defined as the desire to eat, usually associated with the duration of fasting. Satiation is the process that controls meal size and leads to meal termination, characterized by the postprandial perception of fullness or symptoms such as nausea and bloating. The number of calories consumed that is associated with these symptoms allows quantification of satiation $[10,90]$. Satiety denotes the intensity and duration of fullness after reaching satiation, delaying subsequent meal consumption [91]. Therefore, measurements of satiety can be based on subjective feelings or the objective duration of the period of fasting between meals.

Gastric sensory and motor functions are crucial in the regulatory process. During fasting, the stomach releases ghrelin, which induces hunger. At the initiation of the meal, stomach distention induces the sensation of satiation or fullness as originally described by Walter Cannon in 1911 in studies involving inflation of an intragastric balloon [92]. In healthy subjects, liquid preload induced gastric distention (assuming a wider antral area) and decreased both appetite and subsequent food intake [90]. On the other hand, several studies have subsequently found that increased gastric volumes are associated with a higher calorie demand for fullness $[88,93]$. While normal gastric accommodation facilitates food ingestion, an impaired gastric accommodation can cause gastrointestinal symptoms and gastrointestinal disorders, including functional dyspepsia [94,95]. 
The stomach signals sensory information for changes in volume (with or without calories) and pressure to the brain. The stomach also controls the rate of content delivered into the small intestine, thus, regulating further nutrient digestion and coordinating the enteroendocrine hormone release [96]. Gastrointestinal motility and food-activated enteroendocrine signals to the brain contribute to satiation and satiety signals. As absorption in the small intestine is highly efficient, gastric emptying is pivotal in the regulation of energy intake and nutrient absorption [97]. There is a correlation between gastric emptying of solids with the calorie intake at subsequent buffet meals and the volume to fullness. Patients with delayed gastric emptying experience fullness with lower calorie intake [90].

In addition to the neural control of food intake, emptying of nutrients from the stomach to the intestine induces neurohormonal responses. Enteroendocrine cells distributed throughout the gastrointestinal tract sense the nutrient content in the lumen and release hormones to coordinate the sensation of appetite and food consumption [10]. These enteroendocrine hormones induce local paracrine effects and distant endocrine effects, mainly in the central nervous system (CNS) $[38,42,98]$. The transfer of nutrients into the small intestine is essential to stimulate this endocrine control of food intake. The intestinal infusion of macronutrients can regulate appetite, with lipids being the most potent inhibitors of food intake and being highly correlated to hormonal release and gastric motor functions [99-101]. Therefore, the rate of nutrient delivery into the small intestine contributes to the feedback regulation of food intake.

Meal patterns and diet features contribute to the short-term control of food intake mediated by gastric motor functions. For example, four days of fasting promoted a delay in gastric emptying of liquids in patients with normal weight [102]. Timing and meal composition may influence gastric emptying. Whey protein preload has been associated with stimulation of GLP-1 release and slowing of gastric emptying [103-105]. This trend was sustained for four weeks after the intervention, indicating the effect of previous diet on gastric emptying [106]. Other factors such as exogenous fiber added to liquid meals or present in solids produced a small delay in gastric emptying; however, there was no impact on appetite [107-109]. The impact of diet history on gastric emptying highlights the challenge of standardizing results among research participants in studies of gastric functions and food intake.

Basic features such as gender, age, and BMI have been proposed as factors that influence energy intake and alter gastric emptying [110-112]. Gender is the major contributor to differences in gastric motor functions, with gastric emptying being around $15 \%$ slower in females and influencing the energy intake in controlled interventions [64,111]. However, the biochemical mechanisms contributing to the variance is uncertain, and research performed to determine the influence of sex hormones has failed to explain the disparity observed in women [113]. Age does not substantially change the rate of solid food emptying from the stomach, and the reported delay in liquid emptying among older participants is relatively minor and not considered clinically relevant. Still, there is an apparent decrease in caloric intake with aging and the mechanism is incompletely understood [114-116].

The majority of available gastric emptying trials using accurate methods have examined Caucasian patients; hence, the possible effect of ethnicity is uncertain. Data shows that some ethnicities, such as Mexican Americans, American Indians, Ethiopian refugees, and Han Chinese, have more rapid gastric emptying [117-121]. Physical activity may also impact gastric emptying. When compared to sedentary participants, long-distance runners had faster gastric emptying at baseline [122]. A similar pattern has been observed in individuals with obesity, where those engaging in physical exercise have demonstrated increased gastric emptying [123]. Furthermore, gastric emptying may change according to exercise intensity. High-intensity exercise may slow gastric emptying, although mild to moderate exercise has little effect or may accelerate gastric emptying [124,125]. 


\section{Gastric Sensory and Motor Functions in Obesity}

The balance between energy intake and energy expenditure is a simplistic way to understand body weight regulation. An imbalance, mainly due to disruptions in food intake, is a contributor to obesity [2]. In patients with obesity, gastric volume and gastric emptying strongly correlate with hunger and fullness scores [126]. This rise in fasting gastric volumes resulted in delayed satiation, and thus a higher caloric intake is required to induce satiation, favoring weight gain [126,127]. Therefore, all processes involved in controlling gastric functions may affect body weight.

In 1975, Hunt et al. observed an accelerated transfer of calories from the stomach to the duodenum in obese patients, which was thought to lead to shorter duration of satiety [12]. Since then, gastric sensory and motor functions have been evaluated with contradictory findings, that is, both sides: rapid [14,128,129] and delayed gastric emptying have been reported [130-132]. These contradictory findings may be due to confounding factors such as participants' comorbidities; concomitant medications; previous weight loss history; smoking; or study design with different criteria for participant selection, sample size, and non-standardized methods to evaluate gastric sensory and motor functions [66,133-136].

Among 328 participants, in the largest cohort reported to date, obesity was associated overall with accelerated gastric emptying, with an acceleration by 24 and 17 min for solids and 9 and $7 \mathrm{~min}$ for liquids in class I and class II obesity, respectively [14]. There is also evidence in normal and overweight patients that there is a relationship between weight and gastric emptying [14,137]. Furthermore, young adults with more rapid gastric emptying were shown to be more likely to gain weight [138].A larger gastric capacity has also been reported in patients with obesity based on maximum tolerated volume during a nutrient drink test or as measured by an intragastric latex balloon [139-141]. SPECT showed increased fasting gastric volume in participants who were overweight or obese [14,142,143]. Successful dietary weight loss was associated with a decrease in gastric volume [141].

In adult patients with obesity, baseline gastric emptying may be associated with weight loss in response to several types of interventions. The BMI change ranged from $9 \%$ for dietary interventions to 23\% for Roux-Y-gastric bypass (RYGB) (additional details in next section) [82,129,144-146] As weight loss itself, in response to lifestyle interventions, does not seem to affect the gastric emptying rate, we may conclude that gastric emptying facilitates response to treatment [147-152]. As a result, slowing gastric emptying was suggested as one of the pathways for understanding weight loss in response to both pharmacological and endoscopic treatments. This was tested in several randomized, double-blind, placebo-controlled pilot trials with subcutaneous liraglutide and semaglutide and in a randomized, controlled trial with an intragastric balloon where retarding gastric emptying was one significant mechanism of action of those obesity treatments $[90,153,154]$. There is still insufficient proof of the extent of the impact of gastric emptying changes on weight loss, although it has also been shown that obese patients with accelerated gastric emptying will benefit more from specific gastric motility therapy [155].

Many syndromic and non-syndromic types of obesity provide insights into the crucial and complex role of genetics on energy balance, body weight, and the individual's predisposition to obesity [156-158]. Syndromic obesity describes obesity in the clinical sense of a distinct collection of organ-specific abnormalities and additional phenotypes, such as cognitive retardation, developmental abnormalities and hyperphagia [159]. Prader-Willi syndrome is the most prevalent form of syndromic obesity; it is associated with elevated circulating ghrelin levels that lead to the observed hyperphagia [160]. Despite the hypothesis that elevated ghrelin may accelerate gastric emptying, studies have found that gastric emptying in Prader-Willi syndrome is delayed relative to reference values [161,162]. The role of gastric motor functions in other types of syndromic obesity (e.g., leptin deficiency, melanocortin 4 receptor deficiency, Bardet-Biedl syndrome, Alström syndrome) has not been assessed.

Variations in the glucagon-like peptide-1 receptor gene (GLP1R), the melanocortin 4 receptor gene $(M C 4 R)$, Transcription Factor 7 Like 2 (TCF7L2) gene, and CCK gene have 
been studied to understand the influence of genes on gastric emptying rate and are still being studied. Several SNPs (rs742764, rs9283907, rs2268657, and rs2254336) of the GLP1R gene have been associated with statistically significant differences in gastric emptying in a pilot study [163]. The MC4R rs17782313 CC polymorphism was associated with a $6.7 \%$ slower gastric emptying of solids at $2 \mathrm{~h}$ when compared with individuals with the TT genotype [164]. Cremonini et al. found an association between the CCK 779T > C polymorphism and slower gastric emptying rate [165]. The T allele at rs7903146 (TCF7L2) was non-significantly associated with faster gastric emptying [166]. Genetic variation presents a plausible area of investigation, with a specific pharmacogenetic implication as shown by Chedid et al., with GLP1R (rs6923761) being associated with more significant delay in gastric emptying T1/2 in response to liraglutide and exenatide [167].

\section{Treatments of Obesity and Their Effects on Gastric Sensory and Motor Functions \\ 4.1. Lifestyle Interventions}

The first-line treatments for weight management include diet change to achieve substantial caloric deficit, increased exercise to burn calories, and behavioral treatment to improve food and physical activity patterns. Patients do not need to reach a BMI $<25 \mathrm{~kg} / \mathrm{m}^{2}$ in all situations to benefit from weight loss. A sustained weight loss of less than $5 \%$ may help prevent and control diabetes, and modest weight loss of $5 \%$ to $10 \%$ has been associated with substantial improvements in cardiovascular disease risk factors [168,169]. Long-term weight maintenance is therefore essential to reducing the incidence of serious diseases. Exercise has beneficial effects on health besides weight control, but the influence of exercise-induced weight loss on gastric motor function is uncertain [170].

There are limited data available on the impact of diet and exercise-induced weight-loss on gastric motility. Table 2 details the effects of dietary interventions on gastric emptying and energy intake. The main limitations in determining the effects of dietary weight loss on gastric emptying and appetite are variation among subjects, prior dietary patterns, inclusion of patients with poorly regulated diabetes, lack of an effective matched control group, appropriate sample size, complexity in measuring gastric emptying in all settings, and lack of standardization of meals. Despite achieving significant weight-loss, most studies of lifestyle interventions have found no effect on gastric emptying after one month. However, data suggest that a rapid gastric emptying of a solid meal in patients with obesity normalizes after sustained weight loss. Changes in gastric emptying do not appear to correlate with changes in appetite.

Further studies are required to evaluate the impact of fitness programs on gastric emptying.

\subsection{Pharmacological Treatment}

Since the control of food intake is partly mediated through gastric motor functions, delaying gastric emptying may induce a decrease in calorie intake and contribute to the efficacy of weight loss in a majority of patients in the treatment of obesity. Dexfenfluramine, a discontinued anti-obesity agent, significantly slowed gastric emptying of a solid meal in obese patients following short-term therapy ( 5 days and 29 days) relative to placebo, leading to its effectiveness on weight loss [171].

There are five FDA-approved medications for long-term obesity care: orlistat, phentermine/topiramate, bupropion/naltrexone, and liraglutide for adults, orlistat and liraglutide for patients $\geq 12$ years of age; and phentermine for adolescents $\geq 16$ years [172-174]. Table 3 summarizes the effects of anti-obesity medications on gastric emptying in adults. The effects of orlistat on gastric emptying have been investigated in normal-weight healthy volunteers and diabetic overweight subjects where lipase inhibition resulted in a faster emptying of fats but may worsen postprandial glycemia [175-178]. However, these results have not been replicated in patients with obesity and successful weight loss after treatment [179]. In a placebo-controlled, 2-week trial of phentermine/topiramate ER, gastric emptying T1/2 accelerated by $20 \mathrm{~min}$, and the drug's effect on satiation was more pronounced, indicating a significant CNS effect on satiation resulting in the predicted 
weight loss [14]. GLP-1 receptor agonists are a group of GLP-1 drugs that decrease gastric emptying rate and control food intake in patients with obesity $[81,98,180]$. Animal models have demonstrated a decrease in food consumption with bupropion/naltrexone, but this effect and the additional improvements in gastric emptying have not been tested [181].

Six FDA-approved GLP-1 receptor agonists (i.e., exenatide, lixisenatide, liraglutide, dulaglutide, albiglutide, and semaglutide) are available. GLP-1 receptor agonists or GLP1 analogs decrease gastric emptying rate and control food intake in patients with obesity $[81,98,180]$. High-dose liraglutide $(3.0 \mathrm{mg})$ is the only medication in this class approved for long-term obesity treatment. Exenatide was the first to show a weight loss benefit associated with a decrease in gastric emptying [182]. A randomized clinical trial found a correlation between a delay in gastric emptying of solids following treatment with liraglutide $3.0 \mathrm{mg}$ and weight loss [82]. Furthermore, gastric emptying changes may be a biomarker for a response, which may help identify patients for extended therapy [82]. Once-weekly subcutaneous semaglutide, which substantially decreased energy intake, was associated with reducing paracetamol $\mathrm{AUC}_{0-1 \mathrm{~h}}$, strongly suggesting it may slow gastric emptying $[183,184]$.

The short-acting GLP-1RAs (i.e., exenatide twice daily and lixisenatide) [182,185] appear to affect gastric emptying more markedly than longer-acting GLP-1RAs (i.e., exenatide once weekly, liraglutide, dulaglutide, albiglutide, semaglutide) $[82,154,184,186,187]$. However, it is clear that both groups slow gastric emptying, lower pre-prandial and postprandial glucose levels, and promote weight loss. Nausea and vomiting are the most frequently reported gastrointestinal adverse events for GLP-1RAs, especially for longacting formulations, and may contribute to greater weight loss in this group $[188,189]$. The weight loss achieved with subcutaneous semaglutide is independent of gastrointestinal adverse events though other studies confirm that both weekly and oral semaglutide retard gastric emptying $[154,189,190]$. Nevertheless, weight loss associated with GLP-1 receptor agonists may be independent of gastric motor changes and related to central appetite regulation [191-193].

Pramlintide, an amylin analog, at 120 ug three-times-daily or 360 ug two-times-daily, resulted in long-term maintenance of weight loss and delayed gastric emptying [194]. The long-acting amylin analog, BZ043, which is under development, has demonstrated a decline in gastric emptying in animal studies [195]. PYY analogs are currently being developed based on past reports of decreased energy intake in overweight and obese people [196-198]. Studies in healthy humans suggest that the effects might be mediated by a decreased gastric emptying rate, among other potential mechanisms [199]. Further studies are needed to understand the role of other approved anti-obesity drugs on gastric function.

\subsection{Endoscopic Bariatric Procedures}

Endoscopic bariatric therapies (EBT) or procedures have an organ-specific target and mechanism of action [200]. Space-occupying devices are a volume-dependent weight loss therapy that encourages sensation of satiety by promoting gastric distention [141]. Fluid-filled intragastric balloons may also affect gastric emptying to facilitate weight loss $[145,153,201,202]$. However, most of the studies used longitudinal analysis, and only one study was a randomized controlled trial. None of the studies were able to assess possible confounders such as gender, comorbidities, baseline gastric emptying, diet history, and current use of medications.

On meta-analysis, greater changes in gastric emptying were associated with a higher percentage of total body weight lost at six months [203]. Furthermore, gastric emptying at baseline may be a valuable predictor of intolerance since increased baseline gastric retention is correlated with early balloon removal [155]. Therefore, gastric emptying can also help in selection of the appropriate patient for the procedure. Table 4 summarizes the trials evaluating EBTs and gastric emptying.

Other endoscopic restrictive techniques are likely to induce satiety. Endoscopic sleeve gastroplasty is an endoscopic gastric volume reduction technique intended to operate 
similarly to sleeve gastrectomy [204]. Botulinum toxin type A, a neurotoxin and inhibitor of smooth muscle contractility, has been studied because of its potential to slow gastric motility to result in earlier satiety [205]. Intragastric administration of botulinum toxin has been related to transient time and dose-dependent changes in gastric emptying [206,207]. However, the delay in gastric emptying was not associated with weight loss [203].

\subsection{Bariatric Surgery}

Table 4 summarizes the trials evaluating the effects of surgical procedures and gastric emptying.

The principal mechanisms of weight loss after bariatric surgery are malabsorption and gastric restriction. Bariatric surgery may also have beneficial effects on gut hormones, including stimulation of GLP-1 and PYY and modifying gastric motor functions [203,208-211]. These observations are indicative of the potential for other weight loss pathways to be enhanced to induce permanent weight loss.

Sleeve gastrectomy decreases gastric capacity and reduces gastric accommodation, leading to high gastric intraluminal pressure [212]. Changes in the total gastric volume, as well as gut hormones can also affect gastric emptying [213]. In a meta-analysis including 233 patients, sleeve gastrectomy was associated with a mean acceleration of gastric emptying T/2 of $29.2 \mathrm{~min}$ after three months. However, no significant association was found between weight loss at 1-year post-sleeve gastrectomy and gastric emptying [203,214]. Sleeve gastrectomy reduced fasting ghrelin and increased postprandial GLP-1 and PYY. These hormonal changes may impact appetite and reduce food intake [211,215].

RYGB decreased gastric capacity and accelerated the transfer of nutrients as larger particles to the distal small intestine [216]. Additionally, variations in the emptying rate varied between meals where solid emptying was slower and liquid emptying was faster following gastric bypass surgery [149]. A changes in gastric volume may be the primary determinant of weight loss, but it does not adequately explain the impact on the reward system $[211,217]$. Studies indicate that gastric emptying is faster following treatment; however, there is a lack of data in longitudinal studies $[150,151,203,218]$. On the other hand, emptying of solids from the pouch immediately after surgery was associated with increased weight loss [218,219].

Loss of normal accommodation in the gastric remnant and accelerated gastric emptying are likely to play important roles in the effects of RYGB on food intake and glycemic control. Bariatric-surgery procedures have shown, especially in the first months after surgery, to substantially increase GLP-1 secretion, which regulates gastric emptying and is related to the improved meal-related glycemia [220]. These effects might be triggered by directly transferring food to the distal small intestine with higher densities of neuroendocrine L-cells; however, there is still mixed evidence explaining the benefits of surgical procedures $[221,222]$.

Table 2. Effect of low-calorie diets on gastric emptying, energy intake, and appetite in obesity.

\begin{tabular}{|c|c|c|c|c|c|c|}
\hline $\begin{array}{l}\text { Study Design/ } \\
\text { Intervention }\end{array}$ & Methods & $\begin{array}{c}\text { Effect on GI } \\
\text { Motor Function }\end{array}$ & $\begin{array}{l}\text { Weight Loss } \\
\text { BMI, } \mathrm{kg} / \mathrm{m}^{2}\end{array}$ & $\begin{array}{l}\text { Energy Intake } \\
\text { Kcal/Day }\end{array}$ & $\begin{array}{c}\text { Appetite } \\
\text { Sensations, VAS }\end{array}$ & Ref. \\
\hline $\begin{array}{l}\text { RCT, SB in } \\
\text { obesity (BMI } \\
\left.37.4 \pm 4.0 \mathrm{~kg} / \mathrm{m}^{2}\right) \\
(n=42) \\
\text { Diet: } \\
\text { ETEE-600 kcal } \\
\text { (mini- } \\
\text { mum1200 kcal), } \\
\text { exercise and } \\
\text { behavioral } \\
\text { modification. }\end{array}$ & $\begin{array}{l}\text { Scinti-graphic GE } \\
\text { and VAS: Pre and } \\
\text { 1-month post-Rx }\end{array}$ & $\begin{array}{l}\mathrm{GE} \mathrm{T}_{1 / 2} \text { liquids } \\
\text { min: baseline } \\
21.8 \pm 10.1 \\
\text { vs.1-month } \\
24.4 \pm 8.7 ; \mathrm{ns} \\
\text { GE solids } \% / \mathrm{h}: \\
\text { baseline } 30.3 \pm \\
15.2 \text { vs. } 1 \text {-month } \\
26.2 \pm 15.2 ; \mathrm{ns}\end{array}$ & $\begin{array}{l}\text { Baseline } \\
37.4 \pm 3.9 \\
1 \text {-month } \\
36.7 \pm 3.9 \\
\Delta-0.8(95 \% \text { CI } \\
{[-1.0,-0.5]} \\
p<0.001) .\end{array}$ & $\begin{array}{l}\Delta-599.9(95 \% \text { CI } \\
{[-885.6,-315.2]} \\
p<0.001) .\end{array}$ & $\begin{array}{l}\text { Decrease in: } \\
\text { Desire to eat } \\
\text { AUC, Hunger } \\
\text { AUC, and } \\
\text { Fullness AUC }\end{array}$ & [179] \\
\hline
\end{tabular}


Table 2. Cont.

\begin{tabular}{|c|c|c|c|c|c|c|}
\hline $\begin{array}{l}\text { Study Design/ } \\
\text { Intervention }\end{array}$ & Methods & $\begin{array}{c}\text { Effect on GI } \\
\text { Motor Function }\end{array}$ & $\begin{array}{l}\text { Weight Loss } \\
\text { BMI, kg/m² }\end{array}$ & $\begin{array}{l}\text { Energy Intake } \\
\text { Kcal/Day }\end{array}$ & $\begin{array}{c}\text { Appetite } \\
\text { Sensations, VAS }\end{array}$ & Ref. \\
\hline $\begin{array}{l}\text { RCT, DB in } \\
\text { obesity (BMI } \\
\left.37.4 \pm 4.0 \mathrm{~kg} / \mathrm{m}^{2}\right) \\
(n=14) \\
\text { Placebo vs. diet } \\
\text { Diet: } \\
\text { ETEE-600 kcal } \\
\text { (minimum } \\
1200 \text { kcal). }\end{array}$ & $\begin{array}{l}\text { Scinti-graphic GE } \\
\text { and VAS: Pre, 1- } \\
\text { and } 12 \text { months } \\
\text { post-Rx }\end{array}$ & $\begin{array}{l}\mathrm{GE} \mathrm{T}_{1 / 2} \text { liquids } \\
\text { min: } \\
\text { baseline } \\
25.5 \pm 10.7 ; \\
1 \text {-month } \\
19.3 \pm 9.0 ; \\
12 \text {-months } \\
21.8 \pm 10.3 ; \mathrm{ns} \\
\text { GE rate } \% / \mathrm{h} \\
\text { solids: } \\
\text { baseline } \\
26.6 \pm 16.3 \\
1 \text { month: } \\
35.8 \pm 13.8 ; \mathrm{ns} \\
12 \text {-months } \\
\text { 17.6 } \pm 13.0 ; \\
p<0.05 \text { vs } \\
\text { baseline }\end{array}$ & $\begin{array}{l}\text { Baseline: } \\
37.6 \pm 3.9 \\
\text { 1-month: } \\
37.2 \pm 3.9 \\
12 \text { months: } \\
34.2 \pm 5.4 \\
p<0.05\end{array}$ & No effect & No effect & [179] \\
\hline
\end{tabular}

\section{Case-control \\ study \\ Obese (BMI, $\mathrm{kg} / \mathrm{m}^{2}$ : 48 [IQR 45.3-53.8) \\ $(n=10)$. \\ 4 months of \\ low-calorie diet \\ (800-1000 kcal)}

GE rate for solids

Scinti-graphic GE and VAS: Pre vs. 1-month post-Rx
$\% / \min : \Delta 0.80$

(IQR: 0.60-1.15);

$p<0.01$
Weight loss:

$\Delta 9 \%(0.7-23.66) ; \quad$ NA No effect

[129]

\section{Case-control \\ study \\ 19 Obese (mean \\ BMI = \\ $38.7 \mathrm{~kg} / \mathrm{m}^{2}$ ):}

Diet-induced wt

loss.

Low-calorie diet

(1000 kcal/day)

for 8 weeks, then

energy-restricted

(1500 kcal/day)

for 8 weeks,

then

maintenance

diet for 8 weeks

(ETEE286 kcal)

\section{Cross-sectional}

study

8 Obese (Weight:

$148.9 \mathrm{~kg}$

[IQR 81-240)

3 to 4 weeks of a very-low calorie

diet.
GE solids \% at

30 min:

Baseline $24.0(95 \%$

CI $(18.4,29.5))$,

24-weeks: 18.3

(95\% CI (14.0,

Scinti-graphic GE: $\quad 22.6)) ; p<0.02)$

Pre and 24 weeks

post-Rx

GE solids

$\mathrm{AUC}_{0-60 \mathrm{~min}}$

$\%$ min: Baseline

4903 (95\% CI

$(4678,5127))$

24-wks 4651 (95\%

CI $(4404,4897))$;

$p<0.03)$
Baseline 38.7 (95\%

CI [37.2, 40.1]) vs.

24 weeks 33.0,

$\Delta-14.7(95 \%$ CI

NA

[223]

$p<0.001)$

NA
$[30.9,35.0])$;

GE for liquids,

min: Baseline 41.0

\pm 7.8 vs. 1 -month

$48.5 \pm 8.7 ; \mathrm{ns}$

Scintigraphic

GE: Pre- vs.

1-month post-Rx

GE for solids,

min: Baseline

$93.0 \pm 11.2$ vs.

1-month

$100.7 \pm 12.6$; ns
Weight loss

(mean $8.3 \mathrm{~kg}$ )

NA

NA

[147]

Abbreviations: AUC: area under the curve; BMI: body mass index; CI: confidence interval; DB double blind; ETEE estimated total energy expenditure; GE: gastric emptying; MIN: minutes; NA: not analyzed; ns: non-significant; VAS: visual analog scale; RCT randomized controlled trial; SB single blind. 
Table 3. Effect of anti-obesity medications on gastric emptying and energy intake.

\begin{tabular}{|c|c|c|c|c|c|}
\hline $\begin{array}{l}\text { Study Design/ } \\
\text { Intervention }\end{array}$ & Methods & $\begin{array}{l}\text { Effect on GI Motor } \\
\text { Function }\end{array}$ & $\begin{array}{l}\Delta \text { Weight, } \\
\text { kg }\end{array}$ & $\begin{array}{l}\text { Energy Intake Ad } \\
\text { Libitum meal }\end{array}$ & Ref. \\
\hline $\begin{array}{l}\text { PC, DB, RCT. } \\
20 \text { obese (BMI } 33.9 \pm 1 \\
\left.\mathrm{~kg} / \mathrm{m}^{2}\right) \text { with accelerated } \\
\text { GE at baseline } \\
\text { Exenatide } \mathrm{SQ}, 5 \mu \mathrm{g} \text { BID } \\
(n=10) \text { or placebo } \\
(n=10)\end{array}$ & $\begin{array}{l}\text { Scintigraphic GE test: } \\
\text { Pre vs. 1-month } \\
\text { post-Rx }\end{array}$ & $\begin{array}{l}\text { GE \% } 1 \text { h: Exenatide } \\
12.4 \% \text { (IQR } 8-18.5) \\
\text { vs. placebo 38.2\% } \\
\text { (IQR 26.6-42.1); } \\
p<0.001 \\
\text { GE T } 1 / 2, \text { min: }_{\text {Exenatide } 187 \text { (IQR }} \\
\text { 141-240) vs. placebo } \\
86 \text { (IQR 73-125); } \\
p<0.001\end{array}$ & $\begin{array}{l}\text { Exenatide }-0.95 \\
\text { (IQR }-0.7-2.1 \text { ) vs. } \\
\text { placebo } 0.55 \text { (IQR } \\
0.3-2.1) ; p=0.23\end{array}$ & No effect & [182] \\
\hline $\begin{array}{l}\text { RCT } \\
\text { Healthy participants } \\
\left(\text { BMI } 29.6 \pm 0.6 \mathrm{~kg} / \mathrm{m}^{2}\right. \\
\left.\text { vs. } 29.5 \pm 1.0 \mathrm{~kg} / \mathrm{m}^{2}\right) \\
\text { Exenatide } 2.0 \mathrm{mg} \mathrm{SQ} \\
\text { weekly }(n=16) \mathrm{vs} . \\
\text { placebo }(n=16)\end{array}$ & $\begin{array}{l}\text { Scintigraphic GE test: } \\
\text { Pre vs. 2-months } \\
\text { post-Rx }\end{array}$ & $\begin{array}{l}\text { GE for solids } \\
\text { AUC }_{0-120 \mathrm{~min}} \text { : } \\
\text { Exenatide slowed } \\
\text { GE vs. placebo; } \\
p=0.046 \\
\text { GE for liquids } \\
\text { AUC }_{0-120 \mathrm{~min}:} \\
\text { Exenatide slowed } \\
\text { GE vs. placebo; } \\
p=0.01\end{array}$ & $\begin{array}{l}\text { Exenatide }-2.1 \pm \\
0.5 \text { vs. placebo } 0.2 \pm \\
0.5 ; p=0.001\end{array}$ & NA & [186] \\
\hline $\begin{array}{l}\text { PC, DB, RCT. } 40 \text { obese } \\
\left(\text { BMI: } 34.6 \mathrm{~kg} / \mathrm{m}^{2} \mathrm{vs} .\right. \\
\left.37.2 \mathrm{~kg} / \mathrm{m}^{2}\right) \\
\text { Liraglutide group } \\
(n=19) \mathrm{vs} . \text { placebo } \\
(n=21) \\
\text { Liraglutide or placebo } \\
\text { dose: } 0.6 \mathrm{mg} \\
\text { increments to } 3.0 \mathrm{mg} \\
\text { daily. }\end{array}$ & $\begin{array}{l}\text { Scintigraphic GE test } \\
\text { and VAS: Pre vs. } \\
\text { 16-weeks post-Rx }\end{array}$ & $\begin{array}{l}\mathrm{GE} \mathrm{T}_{1 / 2} 16 \text { weeks, } \\
\text { min: Liraglutide } 142 \\
\text { (IQR } 120-177) \text { vs. } \\
\text { placebo } 113 \text { min } \\
\text { (IQR 101-133); ns } \\
\text { GE T }_{1 / 2} 16 \text { weeks vs } \\
\text { baseline, min: } \\
\text { Liraglutide } 30.5 \text { (IQR } \\
\text {-11-54) vs. placebo } 1 \\
\text { min (IQR -19-7); } \\
p=0.025\end{array}$ & $\begin{array}{l}\text { Liraglutide } 5.3 \text { (IQR } \\
5.2-6.8 \text { ) vs. placebo } \\
2.5 \text { (IQR } 0.1-4.2 \text { ); } \\
p=0.0009\end{array}$ & No effect & $\begin{array}{l}{[82,} \\
224]\end{array}$ \\
\hline $\begin{array}{l}\text { OL, three-arm, RCT } \\
\text { 142 Participants with } \\
\text { T2DM (BMI } 30.8 \pm 0.34 \\
\mathrm{~kg} / \mathrm{m}^{2} \text { ) } \\
\text { Rx + insulin glargine } \\
\text { for } 8 \text { wks: } \\
\text { a) Lixisenatide } 20 \mu \mathrm{g} \\
\text { SQ daily } \\
\text { b) Liraglutide } 1.2 \mathrm{mg} \\
\text { SQ daily } \\
\text { c) Liraglutide } 1.8 \mathrm{mg} \\
\text { SQ daily }\end{array}$ & $\begin{array}{l}{ }^{13} \mathrm{C} \text {-sodium- } \\
\text { octanoic acid } \\
\text { GE test: Pre vs. } \\
\text { 2-months post-Rx }\end{array}$ & $\begin{array}{l}\mathrm{GE}_{1 / 2} 8 \text { weeks vs. } \\
\text { baseline, min: } \\
\text { Lixisenatide } 20 \mu \mathrm{g} \\
453.6 \pm 58.2 ; \\
p<0.001 \\
\text { Liraglutide } 1.2 \mathrm{mg} \\
175.3 \pm 58 ; p<0.05 \\
\text { Liraglutide } 1.8 \mathrm{mg} \\
130.5 \pm 60.3 ; p<0.05\end{array}$ & $\begin{array}{l}\text { Lixisenatide } 20 \mu \mathrm{g} \\
-1.6 \pm 0.5 ; \\
p<0.05 \\
\text { Liraglutide } 1.2 \mathrm{mg} \\
-1.8 \pm 0.5 ; \\
p<0.05 \\
\text { Liraglutide } \\
1.8 \mathrm{mg}-2.4 \pm 0.5 ; \\
p<0.001\end{array}$ & NA & [225] \\
\hline $\begin{array}{l}\text { OL, parallel-group, } \\
\text { RCT } \\
\text { Participants with } \\
\text { T2DM } \\
\text { Lixisenatide of } 20 \mu \mathrm{g} \\
\text { SQ daily }(n=69) \mathrm{vs} \text {. } \\
\text { Sitagliptin } 50 \mathrm{mg} \text { oral } \\
\text { daily }(n=67) \\
\text { Lixisenatide weekly } 5 \\
\mu \text { increments: from } 10 \\
\mu g \text { to } 20 \mu \text { daily. }\end{array}$ & $\begin{array}{l}{ }^{13} \text { C-sodium- } \\
\text { octanoic acid } \\
\text { GE test: Pre vs. } \\
\text { 1-month post-Rx. }\end{array}$ & $\begin{array}{l}\text { Lixisenatide vs. } \\
\text { sitagliptin } \\
\text { GE AUC }_{0-240 \mathrm{~min}} \\
\text { mean change from } \\
\text { baseline, ng/mL: } \\
-4.8 \pm 0.47 \text { vs. } 0.9 \pm \\
0.48(-5.8[-7.10 \\
-4.44] ; p<0.0001)\end{array}$ & $\begin{array}{l}\text { Lixisenatide }-0.41 \\
\text { vs. sitagliptin }+0.39 \\
\text { (descriptive statistics } \\
\text { only) }\end{array}$ & NA & [226] \\
\hline
\end{tabular}


Table 3. Cont.

\begin{tabular}{|c|c|c|c|c|c|}
\hline $\begin{array}{l}\text { Study Design/ } \\
\text { Intervention }\end{array}$ & Methods & $\begin{array}{l}\text { Effect on GI Motor } \\
\text { Function }\end{array}$ & $\begin{array}{l}\Delta \text { Weight, } \\
\quad \text { kg }\end{array}$ & $\begin{array}{l}\text { Energy Intake Ad } \\
\text { Libitum meal }\end{array}$ & Ref. \\
\hline $\begin{array}{l}\text { DB, } \mathrm{X}-\mathrm{O}, \mathrm{RCT} \\
8 \text { obese (BMI } 30.3 \pm 1.0 \\
\left.\mathrm{~kg} / \mathrm{m}^{2}\right) \text { with T2DM } \\
\text { Lixisenatide } 10-\mu \mathrm{g} \mathrm{SQ} \\
\text { for } 14 \text { days and } 20-\mu \mathrm{g} \\
\text { for additional } 14 \text { days }\end{array}$ & $\begin{array}{l}{ }^{13} \text { C-octanoate } \\
\text { GE test: } \\
\text { 1-month post-Rx }\end{array}$ & $\begin{array}{l}\text { GE } \text { AUC }_{1-8 h}: \\
\text { reduced after } \\
\text { lixisenatide } \\
\text { compared with after } \\
\text { placebo; } p=0.048\end{array}$ & $\begin{array}{l}\text { Lixisenatide }-2.4 \pm \\
4.73 \text { vs. placebo }-1.5 \\
\pm 4.24 ; \text { ns }\end{array}$ & NA & [227] \\
\hline $\begin{array}{l}\text { PC, DB, RCT. } \\
30 \text { patients with T2DM } \\
\left(\text { BMI } 32.1 \pm 5.1 \mathrm{~kg} / \mathrm{m}^{2}\right) \\
\text { Lixisenatide }(n=19) \mathrm{vs} \text {. } \\
\text { placebo }(n=21) \\
\text { Lixisenatide or placebo } \\
\text { dose was double } \\
\text { weekly from } 0.5 \mu \mathrm{g} \\
\text { until a dose of } 20 \mu \mathrm{g} \\
\text { daily was reached. }\end{array}$ & $\begin{array}{l}\text { Scintigraphic GE test: } \\
\text { Pre- vs. 8-weeks. } \\
\text { post-Rx }\end{array}$ & $\begin{array}{l}\text { Gastric retention } \\
\text { post-Rx } \\
\text { AUC }_{0-240 \mathrm{~min}}: \\
\text { Adjusted geometric } \\
\text { means for } \\
\text { lixisenatide vs. } \\
\text { placebo } 2.19(95 \% \mathrm{CI} \\
1.82,2.64 ; p<0.001)\end{array}$ & $\begin{array}{l}\text { Lixisenatide }-1.20 \pm \\
5.22 \text { vs. placebo }-1.0 \\
\pm 6.22 ; \text { ns }\end{array}$ & NA & [228] \\
\hline $\begin{array}{l}\text { DB, PC, RCT. } \\
24 \text { obese (BMI } 30.3 \pm \\
\left.1.0 \mathrm{~kg} / \mathrm{m}^{2}\right) \\
\text { Phentermine/ } \\
\text { topiramate } 3.75 \mathrm{mg} \text { and } \\
23 \mathrm{mg} \text {, respectively, for } \\
\text { the first } 5 \text { days, and } 7.5 \\
\text { mg and } 46 \mathrm{mg} \text { for } 10 \\
\text { days }\end{array}$ & $\begin{array}{l}\text { Scintigraphic GE test: } \\
\text { Pre- vs. 2-weeks. } \\
\text { post-Rx }\end{array}$ & $\begin{array}{l}\text { Phentermine/ } \\
\text { topiramate vs. } \\
\text { placebo } \\
\mathrm{GE} \mathrm{T}_{1 / 2} \text { Phenter- } \\
\text { mine/Topiramate vs. } \\
\text { placebo, min: } 109.0 \\
\pm 7 \text { vs. } 88 \pm 7 ; p= \\
0.05\end{array}$ & $\begin{array}{l}\text { Phentermine/ } \\
\text { topiramate }-1.42 \pm \\
0.4 \text { vs. placebo }-0.23 \\
\pm 0.4 \\
p=0.03\end{array}$ & $\begin{array}{l}\text { Phentermine- } \\
\text { topiramate vs. } \\
\text { placebo } \Delta-260(95 \% \\
\text { CI [-491.6, }-28.3] \\
p<0.05)\end{array}$ & [14] \\
\hline
\end{tabular}

Abbreviations: AUC: area under the curve; BMI: body mass index; CI: confidence interval; DB double blind; GE: gastric emptying; IQR: inter quantile range; MIN: minutes; NA: not analyzed; ns: non-significant; OL open label; RCT randomized controlled trial; RX prescription; SB single blinded; SE: standard error; T2DM: type 2 diabetes mellitus; VAS: visual analog scale; WKS weeks; X-O cross over.

Table 4. Effect of bariatric endoscopy on gastric emptying and energy intake.

\begin{tabular}{|c|c|c|c|c|}
\hline $\begin{array}{l}\text { Study Design/ } \\
\text { Intervention }\end{array}$ & Methods & $\begin{array}{l}\text { Effect on GI Motor } \\
\text { Function }\end{array}$ & Weight Loss & Ref. \\
\hline $\begin{array}{l}10 \text { subjects }(B M I \\
\left.32.4 \pm 1.53 \mathrm{~kg} / \mathrm{m}^{2}\right) \\
\text { IGB filled with } 200-229 \\
\text { mL of air for } 12 \text { weeks. }\end{array}$ & $\begin{array}{l}\text { Scintigraphic } \\
\text { GE test: pre- and 5-wks. } \\
\text { post-Tx }\end{array}$ & $\begin{array}{l}\mathrm{GE} \mathrm{T}_{1 / 2} \text { for solids, min: } \\
\text { baseline } 57 \pm 27.8 \text { vs. } \\
\text { 5-weeks. Post-Tx. } \\
67 \pm 27.5 ; p<0.05\end{array}$ & $\begin{array}{l}\Delta 3 \text { months-BL, kg: } \\
-2.4 \pm 1.04\end{array}$ & [229] \\
\hline $\begin{array}{l}15 \text { subjects (BMI } \\
\left.34.4 \pm 0.7 \mathrm{~kg} / \mathrm{m}^{2}\right) \\
\text { IGB filled with } 600 \mathrm{~mL} \text { of } \\
\text { saline for } 24 \text { weeks. }\end{array}$ & $\begin{array}{l}{ }^{13} \mathrm{C} \text {-octanoate } \\
\text { GE test: pre- and } 16-w k s . \\
\text { post-Tx }\end{array}$ & $\begin{array}{l}\mathrm{GE} \mathrm{T}_{1 / 2} \text { for solids, min: } \mathrm{BL} \\
92 \pm 45 \text { vs. } 16 \text {-weeks. } \\
\text { post-Tx } 157 \pm 70 ; p=0.052\end{array}$ & $\begin{array}{l}\text { Body weight loss, \%: } \\
9.4 \pm 1.8\end{array}$ & [201] \\
\hline $\begin{array}{l}3 \text { subjects }(\mathrm{BMI} \\
\left.40.93 \pm 8.8 \mathrm{~kg} / \mathrm{m}^{2}\right) \\
\text { IGB filled with } 500 \mathrm{cc} \text { of } \\
\text { saline for } 24 \text { weeks. }\end{array}$ & $\begin{array}{l}\text { Scintigraphic } \\
\text { GE test: pre- and 3-months } \\
\text { post-Tx }\end{array}$ & $\begin{array}{l}\mathrm{GE} \mathrm{T}_{1 / 2} \text { for solids, min: } \mathrm{BL} \\
114 \pm 18.5 \text { vs.12-weeks. } \\
\text { post-Tx } 375.3 \pm 207 ; \\
p=0.02\end{array}$ & $\begin{array}{l}\Delta 6 \text { months-BL, kg: } \\
-14.67 \pm 4.33\end{array}$ & [202] \\
\hline $\begin{array}{l}7 \text { subjects }(\mathrm{BMI} \\
\left.33.76 \pm 1.78 \mathrm{~kg} / \mathrm{m}^{2}\right) \\
\text { IGB filled with } 500 \mathrm{cc} \text { of } \\
\text { saline for } 24 \text { weeks. }\end{array}$ & $\begin{array}{l}\text { Scintigraphic } \\
\text { GE test: pre- and 3-months } \\
\text { post-Tx }\end{array}$ & $\begin{array}{l}\mathrm{GE}_{1 / 2} \text { for liquids, min: } \\
\text { BL } 38.71 \pm 15.91 \text { vs. } \\
\text { 12-wks. } 318.71 \pm 168.07 \\
p=0.001\end{array}$ & $\begin{array}{l}\Delta 6 \text { months-BL, kg: } \\
-13.14 \pm 2.5\end{array}$ & [202] \\
\hline
\end{tabular}


Table 4. Cont

\begin{tabular}{cccc}
\hline $\begin{array}{c}\text { Study Design/ } \\
\text { Intervention }\end{array}$ & Methods & $\begin{array}{c}\text { Effect on GI Motor } \\
\text { Function }\end{array}$ & Weight Loss \\
\hline
\end{tabular}

15 subjects (BMI

$\left.34.7 \pm 3.42 \mathrm{~kg} / \mathrm{m}^{2}\right)$ vs. 14

controls (BMI

$\left.35.6 \pm 2.84 \mathrm{~kg} / \mathrm{m}^{2}\right)$

IGB + lifestyle (1000-1500

kcal) vs. lifestyle

intervention alone

IGB filled with $550 \mathrm{cc}$ of

saline for 24 weeks.

Lifestyle intervention:

Diet: (1000-1500 kcal),

exercise, behavioral $\mathrm{Rx}$

$\begin{array}{ll}24 \text { subjects }(\mathrm{BMI} & \text { Scintigraphic } \\ \left.35.58 \pm 2.79 \mathrm{~kg} / \mathrm{m}^{2}\right) & \text { GE test: pre- and 2-months } \\ \text { IGB filled with } 600 \mathrm{cc} \text { of } & \text { post-IGB } \\ \text { saline for } 24 \text { weeks. } & \end{array}$

20 subjects (BMI

$51.7 \mathrm{~kg} / \mathrm{m}^{2}$ )

BPD-DS

Scintigraphic

GE test: 3.5y

postoperatively
GE test: pre- and 816-wks. post-IGB
Scintigraphic
Gastric retention at 120

min after 8 weeks, \%: IGB

$61.4 \pm 23.2$ vs. controls

$25.7 \pm 18 ; p=0.003$

Gastric retention at 120

min after 16 weeks, \%: IGB

$62.1 \pm 16.4$ vs. controls

$18.7 \pm 15.6 ; p<0.001$ $\triangle 26$ wks-BL, \%TBW: IGB

$-14 \pm 7.8$ vs. controls $-5.4 \quad$ [153]

$\pm 4 ; p=0.003$
GE $\mathrm{T}_{1 / 2}$ for solids, min: BL

$117.92 \pm 150.23$ vs.

12-weeks. post-Tx 281.48

$\pm 206.49 ; p=0.004$

$\mathrm{GE} \mathrm{T}_{1 / 2}$ for solids, min:

BPD-DS $28 \pm 16$ vs.

laboratory control $(n=160)$

$91 \pm 20$
$\Delta 6$ months-BL, kg:

$-17.09 \pm 3.34 ; p<0.001$

[230]

$\Delta 3.5$ years-BL BMI,

$\mathrm{kg} / \mathrm{m}^{2}: 51.7$ vs. 31.3 (IQR

21.8-46.3)

GE rate, \%/h: BL 42 (IQR

23.3-59) vs. 24-weeks.

16 subjects (BMI

$47.8 \pm 1.7 \mathrm{~kg} / \mathrm{m}^{2}$ )

Gastric banding
Scintigraphic

GE test: pre- and 6-months post-GB
post-Tx 38 (IQR 31-71); ns

Fundus emptying rate,

\%/h: BL 59 (IQR 37-91) vs.

24-weeks. post-Tx 70 (IQR

53-89); ns
$\Delta 6$ months-BL BMI,

$\mathrm{kg} / \mathrm{m}^{2}:-6.1 \pm 0.66$;

$p<0.001$

GE $\mathrm{T}_{1 / 2}$ for liquids, $\mathrm{min}$ :

GB $7 \pm 3$ vs. controls $15 \pm$

$2 ;(p<0.005)$

33 subjects (weight

[149]

$28 \pm 3$
$76 \pm 4.0 \mathrm{~kg}$ )

Scintigraphic GE test:

12-months post-GB

vs. controls $(n=11)$

GE $T_{1 / 2}$ for solids: 8

patients showed slower GE

$\mathrm{T}_{1 / 2}$ for solids $(147 \pm 25$

min) vs. controls (70 \pm 7

$\min$ )

\section{9 subjects \\ Jejunoileal Bypass}

11 subjects, BMI 46.8

$\mathrm{kg} / \mathrm{m}^{2}$ (IQR 35.8-62.5)

Laparoscopic Gastric

Sleeve

Scintigraphic

GE test: 2- and 12-months

post-surgical

Scintigraphic GE test: preand 6-months post-LSG
GE $\mathrm{T}_{60 \text { min }}, \%: 2$ months 70

\pm 24 vs. 12 months $89 \pm 7$; $p<0.05$

GE $\mathrm{T}_{1 / 2}, \mathrm{~min}$ : BL $94.3 \pm$

15.4 vs. 6 months $47.6 \pm$

23.2; $p<0.01$

GE at $90 \mathrm{~min}, \%$ : BL $49.2 \pm$

8.7 vs. 6 months $75.4 \pm$

$14.9 ; p<0.01$
21 subjects (BMI

$45.09 \pm 6.2 \mathrm{~kg} / \mathrm{m}^{2}$ )

Laparoscopic Gastric

Sleeve

20 subjects underwent

LSG

(BMI $38.3 \mathrm{~kg} / \mathrm{m}^{2}$ [IQR

34.5-48.3])

vs. 18 controls

(BMI 19.8-23.5 kg/m²)
Scintigraphic GE test: preand 3-months post-LSG
GE $T_{1 / 2}$, min: BL $62.39 \pm$ 19.83 vs. 3 months $56.79 \pm$ $18.72(p=0.36, \mathrm{t}=-0.92, \mathrm{~ns})$ $\triangle 3$ months-BL, kg:

$-7.29 \pm 1.87 ; p<0.001$

[235]

GE $T_{1 / 2}$ for liquids: control vs post-surgical, min: $34.9 \pm$ 24.6 vs. $13.6 \pm 11.9 ; p<0.01$ $\mathrm{GE} \mathrm{T}_{1 / 2}$ for solids: control vs post-surgical, $\min : 78 \pm$ 15.01 vs. $38.3 \pm 18.77$; $p<0.01$

$\Delta 12$ months-BL, kg:

$42.3 \pm 10.9 ; p<0.001$

[233]

$\Delta 6$ months-BL, kg:

$42.3 \pm 10.9 ; p<0.001$

[234]

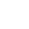


Table 4. Cont.

\begin{tabular}{|c|c|c|c|c|}
\hline $\begin{array}{l}\text { Study Design/ } \\
\text { Intervention }\end{array}$ & Methods & $\begin{array}{l}\text { Effect on GI Motor } \\
\text { Function }\end{array}$ & Weight Loss & Ref. \\
\hline $\begin{array}{l}23 \text { subjects underwent } \\
\text { LSG (BMI } 40.7 \pm 6.6 \\
\left.\mathrm{~kg} / \mathrm{m}^{2}\right) \text { vs. } 44 \text { controls, } 24 \\
\text { lean (BMI } 22.2 \pm 2.89 \\
\left.\mathrm{~kg} / \mathrm{m}^{2}\right) \text { and } 20 \text { obese (BMI } \\
\left.37.7 \pm 5.4 \mathrm{~kg} / \mathrm{m}^{2}\right)\end{array}$ & $\begin{array}{l}\text { Scintigraphic GE test: } 2 \\
\text { years post-LSG }\end{array}$ & $\begin{array}{l}\mathrm{GE} \mathrm{T}_{1 / 2} \text { for solids, } \mathrm{min} \text { : } \\
\text { lean } 72.8 \pm 29.6 \text { vs. } \\
\text { post-surgical } 52.8 \pm 13.5 \\
p=0.025 \\
\mathrm{GE} \mathrm{T}_{1 / 2} \text { for solids, } \mathrm{min} \text { : } \\
\text { obese controls } 73.7 \pm 29.0 \\
\text { vs. post-surgical } 52.8 \pm \\
13.5 ; p=0.01\end{array}$ & $\begin{array}{l}\Delta 12 \text { months-BL, kg: } \\
-26.80 \pm 5.75 ; p<0.001\end{array}$ & [152] \\
\hline $\begin{array}{l}4 \text { subjects underwent } \\
\text { LSG, BMI } 41.9 \mathrm{~kg} / \mathrm{m}^{2}(\mathrm{IQR} \\
38-44.3)\end{array}$ & $\begin{array}{l}\text { Scintigraphic } \\
\text { GE test: pre- and } 3 \text { months } \\
\text { post-LSG }\end{array}$ & $\begin{array}{l}\mathrm{GE}_{1 / 2}, \min : \text { BL } 57.5 \pm \\
12.7 \text { vs. 3-months } 32.25 \pm \\
17.3 ; p=0.016 \\
\text { GE at } 90 \text { min, } \%: \text { BL } 20.5 \text { vs } \\
\text { 3-months } 9.5 ; p=0.073\end{array}$ & $\begin{array}{l}\Delta 3 \text { months-BL, kg: }-7.29 \\
\pm 1.87 ; p<0.001\end{array}$ & [237] \\
\hline $\begin{array}{l}45 \text { subjects underwent } \\
\left.\text { LSG (BMI } 49.5 \mathrm{~kg} / \mathrm{m}^{2}\right)\end{array}$ & $\begin{array}{l}\text { Scintigraphic GE test: pre- } \\
\text { and } 3 \text { months post-LSG }\end{array}$ & $\begin{array}{l}\mathrm{GE}_{1 / 2}, \min : \mathrm{BL} 80.4 \pm \\
33.1 \text { vs. } 3 \text {-months } 64.3 \pm 40 \\
p=0.06\end{array}$ & $\begin{array}{l}\text { Pre-surgical vs. } 12 \text { months } \\
\text { BMI, kg/m²: } 48.5 \text { vs. } 36.8 \\
p<0.05\end{array}$ & [238] \\
\hline $\begin{array}{l}21 \text { subjects underwent } \\
\text { LSG, BMI } 46.8 \mathrm{~kg} / \mathrm{m}^{2} \\
\text { (IQR } 35.8-62.5 \text { ) }\end{array}$ & $\begin{array}{l}\text { Scintigraphic GE test: pre- } \\
\text { and } 4 \text { months post LSG }\end{array}$ & $\begin{array}{l}\mathrm{GE} \mathrm{T}_{1 / 2}, \min : \text { BL } 61.7 \text { (IQR } \\
\text { 37.0-94.3) vs. 4-months } \\
49.1 \text { (IQR 22.4-92.1); } p< \\
0.05\end{array}$ & $\begin{array}{l}\text { Pre-surgical vs. } 6 \text { months } \\
\text { BMI, } \mathrm{kg} / \mathrm{m}^{2}: 46.8 \\
(35.8-62.5) \text { vs. } 37.4 \\
(28.2-53.2)(p<0.05)\end{array}$ & [239] \\
\hline $\begin{array}{l}20 \text { subjects underwent } \\
\text { LSG, BMI } 48.7 \pm 3.3 \mathrm{~kg} / \\
\mathrm{m}^{2}\end{array}$ & $\begin{array}{l}\text { Scintigraphic } \\
\text { GE test: pre- and 1-4 } \\
\text { weeks post-LSG for liquids. }\end{array}$ & $\begin{array}{l}\mathrm{GE}_{1 / 2} \text { for liquids, min: } \\
\text { BL } 25.3 \pm 4.4 \text { vs. } 1 \text {-months } \\
11.8 \pm 3.0 ; p<0.001\end{array}$ & $\begin{array}{l}\Delta 1 \text { month-BL } \\
\text { BMI, kg } / \mathrm{m}^{2}:-8.20 \pm 1.03 \\
p<0.001\end{array}$ & [240] \\
\hline $\begin{array}{l}20 \text { subjects underwent } \\
\text { LSG, BMI } 49.1 \pm 7.1 \mathrm{~kg} / \\
\mathrm{m}^{2}\end{array}$ & $\begin{array}{l}\text { Scintigraphic } \\
\text { GE test: Pre- and } 4-6 \\
\text { weeks post-LSG for solids }\end{array}$ & $\begin{array}{l}\text { GE } \mathrm{T}_{1 / 2} \text { for solids, } \min : \mathrm{BL} \\
74.9 \pm 7.1 \text { vs. } 6 \text {-weeks } 28.4 \\
\pm 8.3 ; p<0.001\end{array}$ & $\begin{array}{l}\Delta 6 \text { weeks-BL } \\
\mathrm{BMI}, \mathrm{kg} / \mathrm{m}^{2}:-11.40 \pm \\
1.86 ; p<0.001\end{array}$ & [240] \\
\hline
\end{tabular}

\section{0 subjects underwent}

LSG, dichotomize according to postprandial symptoms.

Low symptoms score, BMI $45.5 \pm 10.7 \mathrm{~kg} / \mathrm{m}^{2}$ $(n=13)$ vs high symptom score, BMI, $40.5 \pm 4.5 \mathrm{~kg} / \mathrm{m}^{2}(n=7)$

\section{0 subjects underwent LSG, BMI $33.4 \pm 1.2 \mathrm{~kg} /$ $\mathrm{m}^{2}$}

Scintigraphic GE test: 2 years post-LSG.
$\mathrm{GE} \mathrm{T}_{1 / 2}$ for liquids, min: Low symptoms $10.4 \pm 2.9$ vs. high symptom $10.6 \pm$ $4.3 ; p=0.27$

GE $T_{1 / 2}$ for solids, min: Low symptoms $40.6 \pm 10.0$ vs. high symptom $34.4 \pm$ 9.3; $p=0.90$
Group I $\Delta 24$ months-BL BMI, $\mathrm{kg} / \mathrm{m}^{2}:-13.00 \pm$ 3.27; $p<0.05$

Group II $\Delta 24$ months-BL

BMI, $\mathrm{kg} / \mathrm{m}^{2}:-10.50 \pm$ $1.37 ; p<0.05$
GE $\mathrm{T}_{1 / 2}$, min: BL $38.4 \pm 13$ vs. 3 - months $20.3 \pm 7.6$ vs. 6-months $20.7 \pm 9.5$ vs. 12 months $20.6 \pm 4.4 ; p<0.05$

GE $T_{1 / 2}, \min :$ BL $96.5 \pm$ 78.9

vs. 6 -months $44.3 \pm 21.1$ vs. 12-months $36.1 \pm 10.2 ; p<$ 0.001

GE $T_{1 / 2}$, min: BL $99.9 \pm$ 71.4 vs. 6 -months $48,1 \pm$ 21.6 vs. 12 -months $44.4 \pm$ 15.9; $p<0.001$

GE $T_{1 / 2}$ for liquids, min: BL $26.7 \pm 23$ vs. 3-months $15.2 \pm 13 ; p<0.05$

Scintigraphic 50 subjects underwent LSG, BMI $44.5 \pm 8.1 \mathrm{~kg} /$ $\mathrm{m}^{2}$
GE test: pre- and 3-months post-LSG
GE $\mathrm{T}_{1 / 2}$ for solids, min: BL $68.7 \pm 25$ vs. 3 -months 15.2 $\pm 13 ; p<0.05$ $\triangle 3$ months-BL BMI, $\mathrm{kg} / \mathrm{m}^{2}:-5.5 \pm 1.9 ; p<0.05$

$\Delta 12$ months-BL BMI, $\mathrm{kg} / \mathrm{m}^{2}:-17.28 \pm 6.76$; $p<0.05$ $\Delta 12$ months-BL BMI, $\mathrm{kg} / \mathrm{m}^{2}:-16.79 \pm 8.35$; $p<0.05$

\%EWL after 3 months $(n=26): 24.6 \pm 12.1$ $\%$ EWL after 3 months 
Table 4. Cont.

\begin{tabular}{|c|c|c|c|c|}
\hline $\begin{array}{l}\text { Study Design/ } \\
\text { Intervention }\end{array}$ & Methods & $\begin{array}{l}\text { Effect on GI Motor } \\
\text { Function }\end{array}$ & Weight Loss & Ref. \\
\hline $\begin{array}{l}38 \text { subjects underwent } \\
\text { LSG, } 12 \text { with } \\
\text { antrum resection- } 2 \mathrm{~cm} \\
\text { from the pylorus vs. } 13 \\
\text { with antrum } \\
\text { preservation }-5 \mathrm{~cm} \text { from } \\
\text { the pylorus }\end{array}$ & $\begin{array}{l}\text { Scintigraphic } \\
\text { GE test: pre- and 2-months } \\
\text { and 1-year post-LSG }\end{array}$ & $\begin{array}{l}\text { AR pre vs. } 2 \text { months post } \\
\text { LSG GE }_{60-\text { min }} \text { for } \\
\text { semi-solids, } \% \text { : } 55.8 \pm 22 \\
\text { vs. } 69.7 \pm 18 ; \text { ns } \\
\text { AR pre vs. } 12 \text { months post } \\
\text { LSG GE }_{60-\text { min }} \text { for } \\
\text { semi-solids, } \% \text { : } 55.8 \pm 22 \\
\text { vs. } 66.5 \pm 21 ; \text { ns } \\
\text { AP pre vs. } 2 \text { months post } \\
\text { LSG GE } 60-\text { min for } \\
\text { semi-solids, } \%: 52.7 \pm 24 \\
\text { vs. } 72.8 \pm 20 ; p=0.024 \\
\text { AP pre vs. } 12 \text { months post } \\
\text { LSG GE } 60-\text { in for } \\
\text { semi-solids, } \%: 52.7 \pm 24 \\
\text { vs. } 74.2 \pm 16 ; p=0.010\end{array}$ & $\begin{array}{l}\text { AR pre vs. } 12 \text { months } \\
\text { post-LSG BMI, } \mathrm{kg} / \mathrm{m}^{2}: \\
43.01 \text { vs. } 31.43 \\
\text { AP pre vs. } 12 \text { months } \\
\text { post-LSG BMI, } \mathrm{kg} / \mathrm{m}^{2}: 45.3 \\
\text { vs. } 31.88\end{array}$ & [214] \\
\hline $\begin{array}{l}23 \text { subjects underwent } \\
\text { LSG, BMI } 41.9 \pm 5.3 \mathrm{~kg} / \\
\mathrm{m}^{2}\end{array}$ & $\begin{array}{l}\text { Scintigraphic } \\
\text { GE test: pre- and 3-months } \\
\text { post-LSG }\end{array}$ & $\begin{array}{l}\mathrm{GE} \mathrm{T}_{1 / 2} \text { for solids, min: } \mathrm{BL} \\
52.7 \pm 20.5 \text { vs. } 3 \text {-months } \\
33.6 \pm 3.0 ; p<0.001\end{array}$ & $\begin{array}{l}\Delta 3 \text { months-BL BMI, } \\
\mathrm{kg} / \mathrm{m}^{2}: \\
-7 \pm 7.35 ; p<0.001\end{array}$ & [245] \\
\hline $\begin{array}{l}21 \text { subjects underwent } \\
\text { LSG, BMI } 38.89 \pm 7.55 \mathrm{~kg} / \\
\mathrm{m}^{2}\end{array}$ & $\begin{array}{l}\text { Scintigraphic } \\
\text { GE test: pre- and 3-months } \\
\text { post-LSG }\end{array}$ & $\begin{array}{l}\mathrm{GE}_{1 / 2} \text { for solids, min: } \mathrm{BL} \\
67.1 \pm 33.43 \text { vs. } 3 \text {-months } \\
20.71 \pm 12.81 ; p<0.05\end{array}$ & $\begin{array}{l}\Delta 3 \text { months-BL BMI, } \\
\mathrm{kg} / \mathrm{m}^{2}: \\
-8 \pm 9.80 ; p<0.05\end{array}$ & [246] \\
\hline $\begin{array}{l}100 \text { subjects underwent } \\
\text { LSG, BMI } 43.43 \pm 3.8 \mathrm{~kg} / \\
\mathrm{m}^{2}\end{array}$ & $\begin{array}{l}\text { Scintigraphic } \\
\text { GE test: pre- and 3-months } \\
\text { post-LSG }\end{array}$ & $\begin{array}{l}\text { Retention, \%: } \\
1 \text { h: } 64 \pm 13 \text { vs. } 54.5 \pm 15 \\
p<0.0001 \\
2 \text { h: } 45 \pm 12 \text { vs. } 35.5 \pm 13) \\
p<0.0001 \\
4 \text { h: } 6 \pm 3 \text { vs. } 4 \pm 2 \\
p<0.0001\end{array}$ & $\begin{array}{l}\Delta 3 \text { months-BL BMI, } \\
\mathrm{kg} / \mathrm{m}^{2}: \\
-8.83 \pm 4.54 ; p<0.001\end{array}$ & [247] \\
\hline $\begin{array}{l}23 \text { subjects underwent } \\
\text { LSG, BMI } 42.4 \pm 5.8 \mathrm{~kg} / \\
\mathrm{m}^{2}\end{array}$ & $\begin{array}{l}\text { MRI } \\
\text { GE test: pre- and after } 40 \% \\
\text { of EBW loss post-LSG }\end{array}$ & $\begin{array}{l}\text { Total gastric volume, mL: } \\
\text { BL } 467(95 \% \text { CI }(455,585)) \\
\text { vs. post-Tx } 139(95 \% \mathrm{CI} \\
(121,185) ; p<0.0001) \\
\text { Early-phase GE, } \mathrm{mL} / \mathrm{min}: \\
1.9(95 \% \mathrm{CI}(1.1,4.0)) \text { vs. } \\
2.69(95 \% \mathrm{CI}[1.6,3.4] ; p= \\
0.001) \\
\text { Late-phase GE, } \mathrm{mL} / \mathrm{min}: \\
2.5(95 \% \mathrm{CI}(2.0,2.9)) \text { vs. } 1.4 \\
(95 \% \mathrm{CI}(1.1,1.7) ; p=0.001)\end{array}$ & $\begin{array}{l}\Delta 7 \text { months-BL BMI, } \\
\mathrm{kg} / \mathrm{m}^{2}: \\
-9.6 \pm 7.28 ; p<0.001\end{array}$ & [213] \\
\hline $\begin{array}{l}26 \text { subjects underwent } \\
\text { LSG, BMI } 47.5 \pm 6.6 \mathrm{~kg} / \\
\mathrm{m}^{2}\end{array}$ & $\begin{array}{l}\text { Scintigraphic } \\
\text { GE test: after }>20 \% \text { TBWL } \\
\text { post-LSG }\end{array}$ & $\begin{array}{l}\mathrm{GE}_{1 / 2} \text { for solids, min: } \mathrm{BL} \\
24.4 \pm 11.4 \text { vs. post-Tx } \\
75.80 \pm 45.19 ; p<0.001\end{array}$ & $\begin{array}{l}\Delta 8 \text { months-BL BMI, } \\
\mathrm{kg} / \mathrm{m}^{2}: \\
-12.60 \pm 9.99 ; p<0.01\end{array}$ & [248] \\
\hline $\begin{array}{l}10 \text { SG (BMI } 33.4 \pm 2.4 \mathrm{~kg} / \\
\left.\mathrm{m}^{2}\right), 10 \mathrm{RYGB}(\mathrm{BMI} 33.5 \\
\left. \pm 2.1 \mathrm{~kg} / \mathrm{m}^{2}\right), \text { and } 10 \\
\text { controls }(\text { BMI } 33.4 \pm 1.7 \\
\left.\mathrm{kg} / \mathrm{m}^{2}\right)\end{array}$ & $\begin{array}{l}\text { Scintigraphic } \\
\text { GE test: SG vs. RYGB vs. } \\
\text { controls }\end{array}$ & $\begin{array}{l}\mathrm{GE} \mathrm{T}_{1 / 2} \text { for solids, min: } \\
\text { RYGB } 11 \pm 2 ; \text { SG } 56 \pm 11 \\
\text { controls } 113 \pm 8 ; p<0.01\end{array}$ & $\begin{array}{l}\text { BMI loss } \%: \text { SG: } 60 \pm 8 \text { vs. } \\
\text { RYGB: } 61 \pm 7\end{array}$ & [249] \\
\hline
\end{tabular}


Table 4. Cont.

\begin{tabular}{|c|c|c|c|c|}
\hline $\begin{array}{l}\text { Study Design/ } \\
\text { Intervention }\end{array}$ & Methods & $\begin{array}{c}\text { Effect on GI Motor } \\
\text { Function }\end{array}$ & Weight Loss & Ref. \\
\hline $\begin{array}{l}17 \text { RYGB (BMI } 45.8 \pm 4.7 \\
\left.\mathrm{~kg} / \mathrm{m}^{2}\right), \text { and } 9 \text { controls } \\
\left(\mathrm{BMI} 23.5 \pm 1.9 \mathrm{~kg} / \mathrm{m}^{2}\right)\end{array}$ & $\begin{array}{l}\text { Scintigraphic } \\
\text { GE test: Between 15- and } \\
\text { 21-months post-RYGB }\end{array}$ & $\begin{array}{l}\text { Emptying of pouch or } \\
\text { stomach (fraction of total } \\
\text { meal x hours): } \\
\text { Liquid marker, RYGB vs. } \\
\text { controls: } 0.19 \text { (IQR } \\
0.07-0.26 \text { ) vs. } 0.49 \text { (IQR } \\
0.47-0.64) ; p<0.001 \\
\text { Solid marker, RYGB vs. } \\
\text { controls: } 0.45 \text { (IQR } \\
0.31-1.04 \text { ) vs. } 1.33 \text { (IQR } \\
1.15-1.65) ; p=0.004\end{array}$ & $\begin{array}{l}\Delta 18 \text { months-BL BMI, } \\
\mathrm{kg} / \mathrm{m}^{2}: \\
-11.20 \pm 5.32 ; p=0.04\end{array}$ & [250] \\
\hline $\begin{array}{l}10 \text { RYGB (BMI } 29.9 \pm 1.9 \\
\left.\mathrm{~kg} / \mathrm{m}^{2}\right) \text {, and } 10 \text { controls } \\
\left(\mathrm{BMI} 24.3 \pm 0.9 \mathrm{~kg} / \mathrm{m}^{2}\right)\end{array}$ & $\begin{array}{l}\text { Scintigraphic } \\
\text { GE test: } 5 \text { years } \\
\text { post-surgical }\end{array}$ & $\begin{array}{l}\text { RYGB vs. controls } \\
\text { Pouch/GE } \mathrm{T}_{1 / 2}, \text { min: } \\
\text { faster un RYGB; } p<0.001 \\
\text { RYGB Sitting vs. supine } \\
\text { position Pouch/GE } \mathrm{T}_{1 / 2} \\
\text { min: } 2.5 \pm 0.7 \text { vs. } 16.6 \pm \\
5.3 \text { min; } p=0.02\end{array}$ & $\begin{array}{l}\Delta 18 \text { months-BL BMI, } \\
\mathrm{kg} / \mathrm{m}^{2}:-12.9 \pm 3.4 \\
\mathrm{~kg} / \mathrm{m}^{2}\end{array}$ & [221] \\
\hline $\begin{array}{l}8 \text { RYGB, and } 24 \text { controls } \\
\text { (12 lean controls vs. } 12 \\
\text { obese controls) }\end{array}$ & $\begin{array}{l}{ }^{13} \text { C-acetate breath test } \\
\text { GE test: RYGB } 10 \text { weeks } \\
\text { post-surgical }\end{array}$ & $\begin{array}{l}\text { Gastric emptying in lean } \\
\text { controls and obese controls } \\
\text { was significantly slower vs. } \\
\text { RYGB; } p<0.001 \text { ) }\end{array}$ & $\begin{array}{l}\text { Post-surgical BMI, } \mathrm{kg} / \mathrm{m}^{2} \text { : } \\
38.6 \pm 1.7\end{array}$ & [251] \\
\hline $\begin{array}{l}10 \text { RYGB, divided } \\
\text { according TBWL: poor } \\
\text { weight loss }(<25 \%)(n=5) \\
\text { vs. and Successful weight } \\
\text { loss }(>25 \%)(n=5)\end{array}$ & $\begin{array}{l}\text { Scintigraphic } \\
\text { GE test: } 2 \text { years } \\
\text { post-surgical }\end{array}$ & $\begin{array}{l}\text { Poor weight loss vs. } \\
\text { Successful weight loss } \\
\text { Pouch/GE } \mathrm{T}_{1 / 2}, \min : 5.1 \pm \\
1.3 \text { vs. } 34 \pm 32(p=0.12) \\
\text { Poor weight loss vs. } \\
\text { Successful weight loss } \\
\text { PER } \max \% / \text { min: } 17 \pm 4.7 \\
\text { vs. } 5.6 \pm 3.4 ; p=0.002\end{array}$ & $\begin{array}{l}\text { Poor weight loss vs. } \\
\text { Successful weight loss } \\
\text { pre-surgical BMI, } \mathrm{kg} / \mathrm{m}^{2} \text { : } \\
43 \pm 4.3 \text { vs. } 45 \pm 3.8 \\
\text { Poor weight loss vs. } \\
\text { Successful weight loss at } \\
\text { scintigraphy, \%: } 17 \pm 4.1 \\
\text { vs. } 44 \pm 5.7\end{array}$ & [219] \\
\hline $\begin{array}{l}94 \text { subjects underwent } \\
\text { surgery: } 47 \text { RYGB BMI } \\
42.4 \mathrm{~kg} / \mathrm{m}^{2} \text { (IQR } \\
36.0-54.9) \text { and } 47 \text { BRYGB } \\
\text { BMI } 44.3 \mathrm{~kg} / \mathrm{m}^{2} \text { (IQR } \\
21.8-52.5)\end{array}$ & $\begin{array}{l}\text { Scintigraphic } \\
\text { GE test: Between } 6 \text { months } \\
\text { and } 2 \text { years post-surgical }\end{array}$ & $\begin{array}{l}\mathrm{GE} \mathrm{T}_{1 / 2} \text { for solids, min: } \\
\text { RYGB } 65.9 \text { (IQR } 40.6-183.0 \text { ) } \\
\text { vs. BRYGB 79.4 (IQR } \\
41.1-390.9) ; p=0.031\end{array}$ & $\begin{array}{l}\text { RYGB BMI, } \mathrm{kg} / \mathrm{m}^{2}: 42.4 \\
\text { (IQR 36.0-54.9) vs. } 30.9 \\
\text { (IQR 23.7-43.8) } \\
\text { BRYGB BMI, } \mathrm{kg} / \mathrm{m}^{2}: 44.3 \\
\text { (IQR 37.5-60.8) vs. } 29.8 \\
\text { (IQR 21.8-52.5) }\end{array}$ & [146] \\
\hline
\end{tabular}

Abbreviations: AP: antral preservation; AR: Antral resection; AUC: area under the curve; BMI: body mass index; BPD-DS: biliopancreatic diversion with duodenal switch; BRYGB: Banded Roux-en-Y Gastric Bypass; CI: confidence interval; EWL: excess weight loss; GE: gastric emptying; IQR: inter quantile range; LGS: laparoscopic gastric sleeve; MIN: minutes; ns: non-significant; PER: pouch emptying rate; RYGB: Roux-en-Y Gastric Bypass; SE: standard error; TBWL: total body weight loss.

\section{Conclusions}

The effect of the stomach on food intake regulation is mediated by gastric motor and sensory functions, the former controlled by an interconnected net of intrinsic and extrinsic neuroendocrine signals. Gastric emptying and gastric accommodation are associated with appetite sensations, satiation, and satiety signals in health. These functions have been investigated as quantitative traits in relation to the pathophysiology of obesity. Despite advances in the technologies to measure gastric functions, the interpretation and standardization of studies remain challenging, which compromises the analysis of the outcomes. The variability of gastric motor and sensory functions may be influenced but not fully explained by essential characteristics such as gender, age, and weight. In the goal of fully understanding changes in gastric emptying, these variables must be taken into consideration.

Accelerated gastric emptying frequently occurs in patients with obesity. Although the magnitude of weight gain that induces acceleration remains contentious, it is appropriate to 
consider that gastric emptying may be one abnormal quantitative trait in obesity. Delaying gastric emptying by medications, particularly GLP-1 agonists, is a possible successful target for weight loss; however, the extent of the delay to induce weight loss remains controversial. Changes in gastric motility achieved with weight loss diets or surgical procedures may account for improvements in the gut hormone profiles, inducing release of satiety hormones and, thereby, reducing energy intake. On the road towards more personalized management of obesity, identifying patients with this specific trait may allow prediction of those who could most benefit from medications or procedures that retard gastric emptying. Future studies in treating obesity would be enhanced by optimized controlled trials that follow adequate protocols to measure gastric motility, that is, emptying and accommodation, as well as mechanisms controlling appetite, satiation, and satiety.

Author Contributions: All authors have contributed to writing, review, editing, and approval of the final version of the manuscript. All authors have read and agreed to the published version of the manuscript.

Funding: Acosta is supported by NIH (NIH K23-DK114460, C-Sig P30DK84567), ANMS Career Development Award, Mayo Clinic Center for Individualized Medicine-Gerstner Career Development Award. Camilleri receives funding related to obesity from National Institutes of Health (NIH RO1-DK67071).

Institutional Review Board Statement: Not applicable.

Informed Consent Statement: Not applicable.

Data Availability Statement: Not applicable.

Acknowledgments: Figures were created with BioRender.com (accessed on 30 March 2021).

Conflicts of Interest: Acosta is a stockholder in Gila Therapeutics, Phenomix Sciences; he serves as a consultant for Rhythm Pharmaceuticals, General Mills. Camilleri is a stockholder in Phenomix Sciences and Enterin and serves as a consultant to Takeda, Allergan, Rhythm, Kallyope, and Arena with compensation to his employer, Mayo Clinic.

\section{Appendix A}

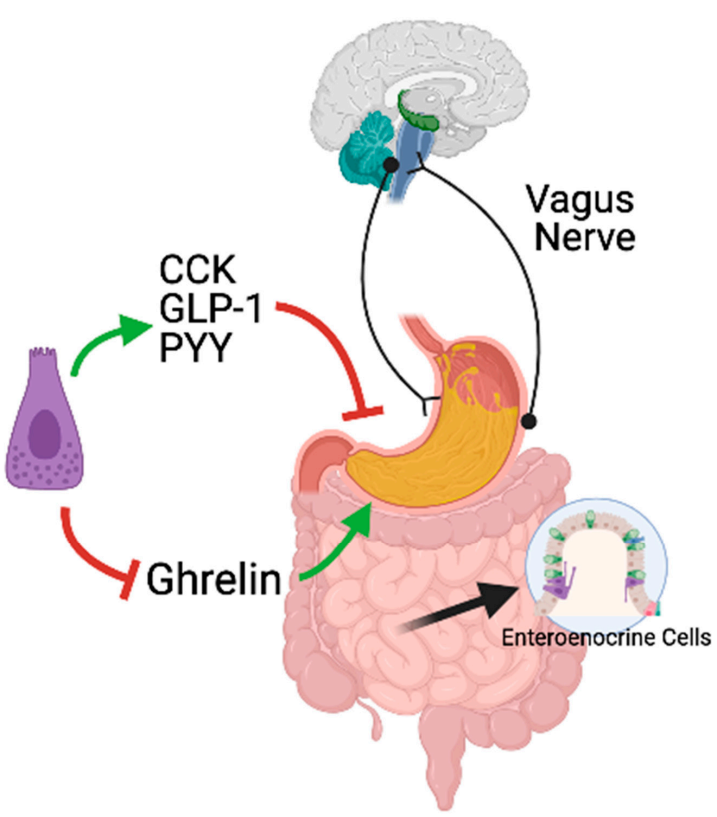

Figure A1. Neural and hormonal regulation of gastric emptying and gastric accommodation in response to meals. The neural regulation of gastric motor functions is commanded by the vagus nerve. The vagus nerve exerts both inhibitory and excitatory effects on the stomach. In response to nutrients, enteroendocrine cells along the gastrointestinal tract secrete CCK, GLP-1, and PYY, which inhibit gastric emptying. In response to the meal, ghrelin secretion, an orexigenic hormone known to stimulate gastric emptying, is blocked. 


\section{References}

1. WHO. Obesity and Overweight. Fact Sheet No 311; WHO Media Centre: 2015. Available online: http://www.who.int/mediacentre/ factsheets/fs311/en/ (accessed on 24 December 2015).

2. Hill, J.O.; Wyatt, H.R.; Peters, J.C. Energy balance and obesity. Circulation 2012, 126, 126-132. [CrossRef] [PubMed]

3. Blundell, J.; de Graaf, C.; Hulshof, T.; Jebb, S.; Livingstone, B.; Lluch, A.; Mela, D.; Salah, S.; Schuring, E.; van der Knaap, H.; et al. Appetite control: Methodological aspects of the evaluation of foods. Obes. Rev. 2010, 11, 251-270. [CrossRef] [PubMed]

4. Acosta, A.; Dayyeh, B.K.A.; Port, J.D.; Camilleri, M. Recent advances in clinical practice challenges and opportunities in the management of obesity. Gut 2014, 63, 687-695. [CrossRef] [PubMed]

5. Alhadeff, A.L.; Rupprecht, L.E.; Hayes, M.R. GLP-1 neurons in the nucleus of the solitary tract project directly to the ventral tegmental area and nucleus accumbens to control for food intake. Endocrinology 2012, 153, 647-658. [CrossRef] [PubMed]

6. Dickson, S.L.; Shirazi, R.H.; Hansson, C.; Bergquist, F.; Nissbrandt, H.; Skibicka, K.P. The glucagon-like peptide 1 (GLP-1) analogue, exendin-4, decreases the rewarding value of food: A new role for mesolimbic GLP-1 receptors. J. Neurosci. 2012, 32, 4812-4820. [CrossRef] [PubMed]

7. Horner, K.M.; Finlayson, G.; Byrne, N.M.; King, N.A. Food reward in active compared to inactive men: Roles for gastric emptying and body fat. Physiol. Behav. 2016, 160, 43-49. [CrossRef] [PubMed]

8. Williams, D.L. Neural integration of satiation and food reward: Role of GLP-1 and orexin pathways. Physiol. Behav. 2014, 136, 194-199. [CrossRef]

9. Rinaman, L. Ascending projections from the caudal visceral nucleus of the solitary tract to brain regions involved in food intake and energy expenditure. Brain Res. 2010, 1350, 18-34. [CrossRef] [PubMed]

10. Camilleri, M. Peripheral mechanisms in appetite regulation. Gastroenterology 2015, 148, 1219-1233. [CrossRef]

11. Hussain, S.S.; Bloom, S.R. The regulation of food intake by the gut-brain axis: Implications for obesity. Int. J. Obes. 2012, 37, 625-633. [CrossRef]

12. Hunt, J.; Cash, R.; Newland, P. Energy density of food, gastric emptying, and obesity. Lancet 1975, 306, 905-906. [CrossRef]

13. Park, M.I.; Camilleri, M. Gastric motor and sensory functions in obesity. Obes. Res. 2005, 13, 491-500. [CrossRef] [PubMed]

14. Acosta, A.; Camilleri, M.; Shin, A.; Vazquez-Roque, M.I.; Iturrino, J.; Burton, D.; O'Neill, J.; Eckert, D.; Zinsmeister, A.R. Quantitative Gastrointestinal and Psychological Traits Associated With Obesity and Response to Weight-Loss Therapy. Gastroenterol. 2015, 148, 537-546.e4. [CrossRef] [PubMed]

15. Jahnberg, T.; Martinson, J.; Hultén, L.; Fasth, S. Dynamic Gastric Response to Expansion before and after Vagotomy. Scand. J. Gastroenterol. 1975, 10, 593-598. [CrossRef] [PubMed]

16. Kuiken, S.D.; Vergeer, M.; Heisterkamp, S.H.; Tytgat, G.N.J.; Boeckxstaens, G.E.E. Role of nitric oxide in gastric motor and sensory functions in healthy subjects. Gut 2002, 51, 212-218. [CrossRef] [PubMed]

17. Camilleri, M.; Malagelada, J.R.; Brown, M.L.; Becker, G.; Zinsmeister, A.R. Relation between antral motility and gastric emptying of solids and liquids in humans. Am. J. Physiol. Liver Physiol. 1985, 249, G580-G585. [CrossRef] [PubMed]

18. Houghton, L.; Read, N.; Heddle, R.; Horowitz, M.; Collins, P.; Chatterton, B.; Dent, J. Relationship of the motor activity of the antrum, pylorus, and duodenum to gastric emptying of a solid-liquid mixed meal. Gastroenterol. 1988, 94, 1285-1291. [CrossRef]

19. Zhang, R.-X.; Wang, X.-Y.; Chen, D.; Huizinga, J.D. Role of interstitial cells of Cajal in the generation and modulation of motor activity induced by cholinergic neurotransmission in the stomach. Neurogastroenterol. Motil. 2011, 23, e356-e371. [CrossRef] [PubMed]

20. Ward, S.M.; Sanders, K.M.; Hirst, G.D.S. Role of interstitial cells of Cajal in neural control of gastrointestinal smooth muscles. Neurogastroenterol. Motil. 2004, 16, 112-117. [CrossRef]

21. Sanders, K.M.; Koh, S.D.; Ro, S.; Ward, S.M. Regulation of gastrointestinal motility—insights from smooth muscle biology. Nat. Rev. Gastroenterol. Hepatol. 2012, 9, 633-645. [CrossRef]

22. Kong, F.; Singh, R. Disintegration of Solid Foods in Human Stomach. J. Food Sci. 2008, 73, R67-R80. [CrossRef]

23. Meyer, J.; Ohashi, H.; Jehn, D.; Thomson, J. Size of liver particles emptied from the human stomach. Gastroenterol. 1981, 80, 1489-1496. [CrossRef]

24. Goyal, R.K.; Hirano, I. The Enteric Nervous System. New Engl. J. Med. 1996, 334, 1106-1115. [CrossRef] [PubMed]

25. Hunt, R.H.; Camilleri, M.; E Crowe, S.; Elomar, E.M.; Fox, J.G.; Kuipers, E.J.; Malfertheiner, P.; McColl, K.E.L.; Pritchard, D.; Rugge, M.; et al. The stomach in health and disease. Gut 2015, 64, 1650-1668. [CrossRef] [PubMed]

26. Furness, J.B. The enteric nervous system and neurogastroenterology. Nat. Rev. Gastroenterol. Hepatol. 2012, 9, 286-294. [CrossRef] [PubMed]

27. Akhavan, T.; Luhovyy, B.L.; Brown, P.H.; E Cho, C.; Anderson, G.H. Effect of premeal consumption of whey protein and its hydrolysate on food intake and postmeal glycemia and insulin responses in young adults. Am. J. Clin. Nutr. 2010, 91, 966-975. [CrossRef]

28. Goyal, R.K.; Guo, Y.; Mashimo, H. Advances in the physiology of gastric emptying. Neurogastroenterol. Motil. 2019, 31, e13546. [CrossRef]

29. Powley, T.L.; Jaffey, D.M.; McAdams, J.; Baronowsky, E.A.; Black, D.; Chesney, L.; Evans, C.; Phillips, R.J. Vagal innervation of the stomach reassessed: Brain-gut connectome uses smart terminals. Ann. N. Y. Acad. Sci. 2019, 1454, 14-30. [CrossRef]

30. Burton, M.; Rolls, E.; Mora, F. Effects of hunger on the responses of neurons in the lateral hypothalamus to the sight and taste of food. Exp. Neurol. 1976, 51, 668-677. [CrossRef] 
31. Matzinger, D.; Degen, L.; Drewe, J.; Meuli, J.; Duebendorfer, R.; Ruckstuhl, N.; D'Amato, M.; Rovati, L.; Beglinger, C. The role of long chain fatty acids in regulating food intake and cholecystokinin release in humans. Gut 2000, 46, 689-694. [CrossRef] [PubMed]

32. Beglinger, C. Effect of Cholecystokinin on Gastric Motility in Humans. Ann. N. Y. Acad. Sci. 1994, 713, 219-225. [CrossRef] [PubMed]

33. A Liddle, R.; Morita, E.T.; Conrad, C.K.; A Williams, J. Regulation of gastric emptying in humans by cholecystokinin. J. Clin. Investig. 1986, 77, 992-996. [CrossRef]

34. Chey, W.; Hitanant, S.; Hendricks, J.; Lorber, S. Effect of Secretin and Cholecystokinin on Gastric Emptying and Gastric Secretion in Man. Gastroenterology 1970, 58, 820-827. [CrossRef]

35. Fried, M.; Erlacher, U.; Schwizer, W.; Löchner, C.; Koerfer, J.; Beglinger, C.; Jansen, J.B.; Lamers, C.B.; Harder, F.; Bischof-Delaloye, A. Role of cholecystokinin in the regulation of gastric emptying and pancreatic enzyme secretion in humans: Studies with the cholecystokinin-receptor antagonist loxiglumide. Gastroenterology 1991, 101, 503-511. [CrossRef]

36. Holst, J.J.; Ørskov, C.; Hartmann, B.; Deacon, C.F. Posttranslational Processing of Proglucagon and Postsecretory Fate of Proglucagon Products. Front. Diabetes 1997, 13, 24-48. [CrossRef]

37. Williams, D.L.; Baskin, D.G.; Schwartz, M.W. Evidence that Intestinal Glucagon-Like Peptide-1 Plays a Physiological Role in Satiety. Endocrinol. 2008, 150, 1680-1687. [CrossRef] [PubMed]

38. I'meryüz, N.; Yeğen, B.C.; Bozkurt, A.; Coşkun, T.; Villanueva-Peñacarrillo, M.L.; Ulusoy, N.B. Glucagon-like peptide-1 inhibits gastric emptying via vagal afferent-mediated central mechanisms. Am. J. Physiol. Gastrointest. Liver Physiol. 1997, 273, G920-G927. [CrossRef] [PubMed]

39. Deane, A.M.; Nguyen, N.Q.; Stevens, J.E.; Fraser, R.J.L.; Holloway, R.H.; Besanko, L.K.; Burgstad, C.; Jones, K.L.; Chapman, M.J.; Rayner, C.K.; et al. Endogenous Glucagon-Like Peptide-1 Slows Gastric Emptying in Healthy Subjects, Attenuating Postprandial Glycemia. J. Clin. Endocrinol. Metab. 2010, 95, 215-221. [CrossRef] [PubMed]

40. Chakraborty, S.; Halland, M.; Burton, D.; Desai, A.; Neja, B.; Low, P.; Singer, W.; Camilleri, M.; Zinsmeister, A.R.; E Bharucha, A. GI Dysfunctions in Diabetic Gastroenteropathy, Their Relationships With Symptoms, and Effects of a GLP-1 Antagonist. J. Clin. Endocrinol. Metab. 2018, 104, 1967-1977. [CrossRef] [PubMed]

41. Näslund, E.; Gutniak, M.; Skogar, S.; Rössner, S.; Hellström, P.M. Glucagon-like peptide 1 increases the period of postprandial satiety and slows gastric emptying in obese men. Am. J. Clin. Nutr. 1998, 68, 525-530. [CrossRef] [PubMed]

42. Nauck, M.A.; Niedereichholz, U.; Ettler, R.; Holst, J.J.; Ørskov, C.; Ritzel, R.; Schmiegel, W.H. Glucagon-like peptide 1 inhibition of gastric emptying outweighs its insulinotropic effects in healthy humans. Am. J. Physiol. Metab. 1997, 273, E981-E988. [CrossRef] [PubMed]

43. Nagell, C.; Wettergren, A.; Pedersen, J.F.; Mortensen, D.; Holst, J.J. Glucagon-like peptide-2 inhibits antral emptying in man, but is not as potent as glucagon-like peptide-1. Scand. J. Gastroenterol. 2004, 39, 353-358. [CrossRef] [PubMed]

44. Miki, T.; Minami, K.; Shinozaki, H.; Matsumura, K.; Saraya, A.; Ikeda, H.; Yamada, Y.; Holst, J.J.; Seino, S. Distinct Effects of Glucose-Dependent Insulinotropic Polypeptide and Glucagon-Like Peptide-1 on Insulin Secretion and Gut Motility. Diabetes 2005, 54, 1056-1063. [CrossRef] [PubMed]

45. Edholm, T.; Degerblad, M.; Grybäck, P.; Hilsted, L.; Holst, J.J.; Jacobsson, H.; Efendic, S.; Schmidt, P.; Hellström, P.M. Differential incretin effects of GIP and GLP-1 on gastric emptying, appetite, and insulin-glucose homeostasis. Neurogastroenterol. Motil. 2010, 22, 1191-e315. [CrossRef] [PubMed]

46. Kar, P.; Jones, K.L.; Horowitz, M.; Chapman, M.J.; Deane, A.M. Measurement of gastric emptying in the critically ill. Clin. Nutr. 2015, 34, 557-564. [CrossRef]

47. Adrian, T.; Ferri, G.-L.; Bacarese-Hamilton, A.; Fuessl, H.; Polak, J.; Bloom, S. Human distribution and release of a putative new gut hormone, peptide YY. Gastroenterology 1985, 89, 1070-1077. [CrossRef]

48. Pironi, L.; Stanghellini, V.; Miglioli, M.; Corinaldesi, R.; de Giorgio, R.; Ruggeri, E.; Tosetti, C.; Poggioli, G.; Morselli^labate, A.M.; Monetti, N.; et al. Fat-induced heal brake in humans: A dose-dependent phenomenon correlated to the plasma levels of peptide YY. Gastroenterology 1993, 105, 733-739. [CrossRef]

49. Batterham, R.L.; Cowley, M.A.; Small, C.J.; Herzog, H.; Cohen, M.A.; Dakin, C.L.; Wren, A.M.; Brynes, A.E.; Low, M.J.; Ghatei, M.A.; et al. Gut hormone PYY3-36 physiologically inhibits food intake. Nat. Cell Biol. 2002, 418, 650-654. [CrossRef]

50. Samsom, M.; Szarka, L.A.; Camilleri, M.; Vella, A.; Zinsmeister, A.R.; Rizza, R.A. Pramlintide, an amylin analog, selectively delays gastric emptying: Potential role of vagal inhibition. Am. J. Physiol. Liver Physiol. 2000, 278, G946-G951. [CrossRef] [PubMed]

51. Bado, A.; Levasseur, S.; Attoub, S.; Kermorgant, S.; Laigneau, J.-P.; Bortoluzzi, M.-N.; Moizo, L.; Lehy, T.; Guerre-Millo, M.; Le Marchand-Brustel, Y.; et al. The stomach is a source of leptin. Nat. Cell Biol. 1998, 394, 790-793. [CrossRef]

52. Martínez, V.; Barrachina, M.-D.; Wang, L.; Taché, Y. Intracerebroventricular leptin inhibits gastric emptying of a solid nutrient meal in rats. Neuro Rep. 1999, 10, 3217-3221. [CrossRef] [PubMed]

53. Cakir, B.; Kasimay, O.; Devseren, E.; Yeğen, B.C. Leptin inhibits gastric emptying in rats: Role of CCK receptors and vagal afferent fibers. Physiol. Res. 2006, 56, 315-322. [PubMed]

54. Sanger, G.J.; Hellström, P.M.; Näslund, E. The hungry stomach: Physiology, disease, and drug development opportunities. Front. Pharmacol. 2011, 1, 145. [CrossRef] [PubMed]

55. Druce, M.R.; Wren, A.M.; Park, A.J.; E Milton, J.; Patterson, M.; Frost, G.; A Ghatei, M.; Small, C.; Bloom, S.R. Ghrelin increases food intake in obese as well as lean subjects. Int. J. Obes. 2005, 29, 1130-1136. [CrossRef] 
56. Meleine, M.; Mounien, L.; Atmani, K.; Ouelaa, W.; Bôle-Feysot, C.; Guérin, C.; Depoortere, I.; Gourcerol, G. Ghrelin inhibits autonomic response to gastric distension in rats by acting on vagal pathway. Sci. Rep. 2020, 10, 1-10. [CrossRef]

57. Camilleri, M.; McCallum, R.W.; Tack, J.; Spence, S.C.; Gottesdiener, K.; Fiedorek, F.T. Efficacy and Safety of Relamorelin in Diabetics With Symptoms of Gastroparesis: A Randomized, Placebo-Controlled Study. Gastroenterology 2017, 153, 1240-1250.e2. [CrossRef]

58. Lembo, A.; Camilleri, M.; McCallum, R.; Sastre, R.; Breton, C.; Spence, S.; White, J.; Currie, M.; Gottesdiener, K.; Stoner, E. Relamorelin Reduces Vomiting Frequency and Severity and Accelerates Gastric Emptying in Adults With Diabetic Gastroparesis. Gastroenterology 2016, 151, 87-96.e6. [CrossRef] [PubMed]

59. Nelson, A.D.; Camilleri, M.; Acosta, A.; Busciglio, I.; Nord, S.L.; Boldingh, A.; Rhoten, D.; Ryks, M.; Burton, D. Effects of ghrelin receptor agonist, relamorelin, on gastric motor functions and satiation in healthy volunteers. Neurogastroenterol. Motil. 2016, 28, 1705-1713. [CrossRef]

60. James, J.; Mair, S.; Doll, W.; Sandefer, E.; Wurtman, D.; Maurer, A.; Deane, A.M.; Harris, M.S. The effects of ulimorelin, a ghrelin agonist, on liquid gastric emptying and colonic transit in humans. Neurogastroenterol. Motil. 2019, 32, e13784. [CrossRef] [PubMed]

61. Wang, X.J.; Burton, D.D.; Breen-Lyles, M.; Camilleri, M. Gastric Accommodation Influences Proximal Gastric and Total Gastric Emptying in Concurrent Measurements Conducted in Healthy Volunteers. Am. J. Physiol. Liver Physiol. 2021. [CrossRef]

62. Schwizer, W.; Maecke, H.; Michael, F. Measurement of gastric emptying by magnetic resonance imaging in humans. Gastroenterology 1992, 103, 369-376. [CrossRef]

63. Abell, T.L.; Camilleri, M.; Donohoe, K.; Hasler, W.L.; Lin, H.C.; Maurer, A.H.; McCallum, R.W.; Nowak, T.; Nusynowitz, M.L.; Parkman, H.P.; et al. Consensus Recommendations for Gastric Emptying Scintigraphy: A Joint Report of the American Neurogastroenterology and Motility Society and the Society of Nuclear Medicine. J. Nucl. Med. Technol. 2008, 36, 44-54. [CrossRef] [PubMed]

64. Camilleri, M.; Iturrino, J.; Bharucha, A.E.; Burton, D.; Shin, A.; Jeong, I.-D.; Zinsmeister, A.R. Performance characteristics of scintigraphic measurement of gastric emptying of solids in healthy participants. Neurogastroenterol. Motil. 2012, 24, 1076-e562. [CrossRef] [PubMed]

65. Camilleri, M.; Zinsmeister, A.R.; Greydanus, M.P.; Brown, M.L.; Proano, M. Towards a less costly but accurate test of gastric emptying and small bowel transit. Dig. Dis. Sci. 1991, 36, 609-615. [CrossRef]

66. Wise, J.L.; Vazquez-Roque, M.I.; McKinney, C.J.; Zickella, M.A.; Crowell, M.D.; Lacy, B.E. Gastric Emptying Scans: Poor Adherence to National Guidelines. Dig. Dis. Sci. 2020, 1-10. [CrossRef] [PubMed]

67. Hveem, K.; Jones, K.L.; E Chatterton, B.; Horowitz, M. Scintigraphic measurement of gastric emptying and ultrasonographic assessment of antral area: Relation to appetite. Gut 1996, 38, 816-821. [CrossRef] [PubMed]

68. Gilja, O.H.; Hausken, T.; Ødegaard, S.; Berstad, A. Gastric emptying measured by ultrasonography. World J. Gastroenterol. 1999, 5, 93-94. [CrossRef] [PubMed]

69. Gilja, O.H.; Lunding, J.; Hausken, T.; Gregersen, H. Gastric accommodation assessed by ultrasonography. World J. Gastroenterol. 2006, 12, 2825-2829. [CrossRef]

70. Gilja, O.; Detmer, P.R.; Jong, J.M.; Leotta, D.F.; Li, X.N.; Beach, K.; Martin, R.; Strandness Jr, D. Intragastric distribution and gastric emptying assessed by three-dimensional ultrasonography. Gastroenterology 1997, 113, 38-49. [CrossRef]

71. Stevens, J.E.; Gilja, O.H.; Gentilcore, D.; Hausken, T.; Horowitz, M.; Jones, K.L. Measurement of gastric emptying of a high-nutrient liquid by 3D ultrasonography in diabetic gastroparesis. Neurogastroenterol. Motil. 2010, 23, 220-e114. [CrossRef]

72. Tefera, S.; Gilja, O.H.; Olafsdottir, E.; Hausken, T.; Hatlebakk, J.G.; Berstad, A. Intragastric maldistribution of a liquid meal in patients with reflux oesophagitis assessed by three dimensional ultrasonography. Gut 2002, 50, 153-158. [CrossRef] [PubMed]

73. Gentilcore, D.; Hausken, T.; Horowitz, M.; Jones, K. Measurements of gastric emptying of low-and high-nutrient liquids using 3D ultrasonography and scintigraphy in healthy subjects. Neurogastroenterol. Motil. 2006, 18, 1062-1068. [CrossRef]

74. Medhus, A.W.; Lofthus, C.M.; Bredesen, J.; Husebye, E. Gastric emptying: The validity of the paracetamol absorption test adjusted for individual pharmacokinetics. Neurogastroenterol. Motil. 2001, 13, 179-185. [CrossRef] [PubMed]

75. Szarka, L.A.; Camilleri, M.; Vella, A.; Burton, D.; Baxter, K.; Simonson, J.; Zinsmeister, A.R. A Stable Isotope Breath Test With a Standard Meal for Abnormal Gastric Emptying of Solids in the Clinic and in Research. Clin. Gastroenterol. Hepatol. 2008, 6, 635-643.e1. [CrossRef] [PubMed]

76. Bluemel, S.; Menne, D.; Fried, M.; Schwizer, W.; Steingoetter, A. On the validity of the13C-acetate breath test for comparing gastric emptying of different liquid test meals: A validation study using magnetic resonance imaging. Neurogastroenterol. Motil. 2015, 27, 1487-1494. [CrossRef] [PubMed]

77. Heading, R.C.; Nimmo, J.; Prescott, L.F.; Tothill, P. The dependence of paracetamol absorption on the rate of gastric emptying. Br. J. Pharmacol. 1973, 47, 415-421. [CrossRef]

78. Willems, M.; Quartero, A.O.; Numans, M.E. How Useful Is Paracetamol Absorption as a Marker of Gastric Emptying? A Systematic Literature Study. Dig. Dis. Sci. 2001, 46, 2256-2262. [CrossRef]

79. Bartholome, R.; Salden, B.; Vrolijk, M.F.; Troost, F.J.; Masclee, A.; Bast, A.; Haenen, G.R. Paracetamol as a Post Prandial Marker for Gastric Emptying, A Food-Drug Interaction on Absorption. PLoS ONE 2015, 10, e0136618. [CrossRef] [PubMed]

80. Horowitz, M.; Rayner, C.K.; Marathe, C.S.; Wu, T.; Jones, K.L. Glucagon-like peptide-1 receptor agonists and the appropriate measurement of gastric emptying. Diabetes, Obes. Metab. 2020, 22, 2504-2506. [CrossRef] [PubMed] 
81. Van Can, J.; Sloth, B.; Jensen, C.B.; Flint, A.; E Blaak, E.; Saris, W.H.M. Effects of the once-daily GLP-1 analog liraglutide on gastric emptying, glycemic parameters, appetite and energy metabolism in obese, non-diabetic adults. Int. J. Obes. 2014, 38, 784-793. [CrossRef]

82. Halawi, H.; Khemani, D.; Eckert, D.; O’Neill, J.; Kadouh, H.; Grothe, K.; Clark, M.M.; Burton, D.D.; Vella, A.; Acosta, A.; et al. Effects of liraglutide on weight, satiation, and gastric functions in obesity: A randomised, placebo-controlled pilot trial. Lancet Gastroenterol. Hepatol. 2017, 2, 890-899. [CrossRef]

83. Maqbool, S.; Parkman, H.P.; Friedenberg, F.K. Wireless Capsule Motility: Comparison of the SmartPill@GI Monitoring System with Scintigraphy for Measuring Whole Gut Transit. Dig. Dis. Sci. 2009, 54, 2167-2174. [CrossRef] [PubMed]

84. Schwizer, W.; Steingotter, A.; Fox, M.; Zur, T.; Thumshirn, M.; Bosiger, P.; Fried, M. Non-invasive measurement of gastric accommodation in humans. Gut 2002, 51, i59-i62. [CrossRef] [PubMed]

85. Chial, H.J.; Camilleri, M.; Delgado-Aros, S.; Burton, D.; Thomforde, G.; Ferber, I. A nutrient drink test to assess maximum tolerated volume and postprandial symptoms: Effects of gender, body mass index and age in health. Neurogastroenterol. Motil. 2002, 14, 249-253. [CrossRef] [PubMed]

86. Kindt, S.; Coulie, B.; Wajs, E.; Janssens, J.; Tack, J. Reproducibility and symptomatic predictors of a slow nutrient drinking test in health and in functional dyspepsia. Neurogastroenterol. Motil. 2008, 20, 320-329. [CrossRef] [PubMed]

87. Tack, J.; Caenepeel, P.; Piessevaux, H.; Cuomo, R.; Janssens, J. Assessment of meal induced gastric accommodation by a satiety drinking test in health and in severe functional dyspepsia. Gut 2003, 52, 1271-1277. [CrossRef] [PubMed]

88. Vijayvargiya, P.; Chedid, V.; Wang, X.J.; Atieh, J.; Maselli, D.; Burton, D.D.; Clark, M.M.; Acosta, A.; Camilleri, M. Associations of gastric volumes, ingestive behavior, calorie and volume intake, and fullness in obesity. Am. J. Physiol. Liver Physiol. 2020, 319, G238-G244. [CrossRef] [PubMed]

89. Blundell, J.E.; Halford, J.C.G. Regulation of nutrient supply: The brain and appetite control. Proc. Nutr. Soc. 1994, 53, 407-418. [CrossRef] [PubMed]

90. Halawi, H.; Camilleri, M.; Acosta, A.; Vazquez-Roque, M.; Oduyebo, I.; Burton, D.; Busciglio, I.; Zinsmeister, A.R. Relationship of gastric emptying or accommodation with satiation, satiety, and postprandial symptoms in health. Am. J. Physiol. Liver Physiol. 2017, 313, G442-G447. [CrossRef]

91. Cannon, W.B.; Washburn, A.L. An Explanation of Hunger 1. Obes. Res. 1993, 1, 494-500. [CrossRef]

92. Cannon, W.B. The Mechanical Factors of Digestion; Longmans, Green \& Company: New York, NY, USA, 1911.

93. Delgado-Aros, S.; Cremonini, F.; Castillo, J.E.; Chial, H.J.; Burton, D.D.; Ferber, I.; Camilleri, M. Independent influences of body mass and gastric volumes on satiation in humans. Gastroenterology 2004, 126, 432-440. [CrossRef]

94. Park, S.-Y.; Acosta, A.; Camilleri, M.; Burton, D.; Harmsen, S.W.; Fox, J.; A Szarka, L. Gastric Motor Dysfunction in Patients With Functional Gastroduodenal Symptoms. Am. J. Gastroenterol. 2017, 112, 1689-1699. [CrossRef] [PubMed]

95. Tack, J.; Piessevaux, H.; Coulie, B.; Caenepeel, P.; Janssens, J. Role of impaired gastric accommodation to a meal in functional dyspepsia. Gastroenterology 1998, 115, 1346-1352. [CrossRef]

96. Blundell, J.E.; Gillett, A. Control of Food Intake in the Obese. Obes. Res. 2001, 9, 263S-270S. [CrossRef] [PubMed]

97. Cummings, D.E.; Overduin, J. Gastrointestinal regulation of food intake. J. Clin. Investig. 2007, 117, 13-23. [CrossRef] [PubMed]

98. Flint, A.; Raben, A.; Rehfeld, J.; Holst, J.; Astrup, A. The effect of glucagon-like peptide-1 on energy expenditure and substrate metabolism in humans. Int. J. Obes. 2000, 24, 288-298. [CrossRef] [PubMed]

99. Chapman, I.M.; A Goble, E.; A Wittert, G.; Horowitz, M. Effects of small-intestinal fat and carbohydrate infusions on appetite and food intake in obese and nonobese men. Am. J. Clin. Nutr. 1999, 69, 6-12. [CrossRef]

100. Feinle-Bisset, C.; Christen, M.; Grundy, D.; Faas, H.; Meier, O.; Otto, B.; Fried, M. Effects of duodenal fat, protein or mixed-nutrient infusions on epigastric sensations during sustained gastric distension in healthy humans. Neurogastroenterol. Motil. 2002, 14, 205-213. [CrossRef] [PubMed]

101. Matzinger, D.; Gutzwiller, J.-P.; Drewe, J.; Orban, A.; Engel, R.; D'Amato, M.; Rovati, L.; Beglinger, C. Inhibition of food intake in response to intestinal lipid is mediated by cholecystokinin in humans. Am. J. Physiol. Content 1999, 277, R1718-R1724. [CrossRef]

102. Corvilain, B.; Abramowicz, M.; Féry, F.; Schoutens, A.; Verlinden, M.; Balasse, E.; Horowitz, M. Effect of short-term starvation on gastric emptying in humans: Relationship to oral glucose tolerance. Am. J. Physiol. Liver Physiol. 1995, 269, G512-G517. [CrossRef] [PubMed]

103. Ma, J.; Stevens, J.E.; Cukier, K.; Maddox, A.F.; Wishart, J.M.; Jones, K.L.; Clifton, P.M.; Horowitz, M.; Rayner, C.K. Effects of a Protein Preload on Gastric Emptying, Glycemia, and Gut Hormones After a Carbohydrate Meal in Diet-Controlled Type 2 Diabetes. Diabetes Care 2009, 32, 1600-1602. [CrossRef] [PubMed]

104. Watson, L.E.; Phillips, L.K.; Wu, T.; Bound, M.J.; Checklin, H.; Grivell, J.; Jones, K.L.; Horowitz, M.; Rayner, C.K. Title: Differentiating the effects of whey protein and guar gum preloads on postprandial glycemia in type 2 diabetes. Clin. Nutr. 2019, 38, 2827-2832. [CrossRef]

105. Watson, L.E.; Phillips, L.K.; Wu, T.; Bound, M.J.; Checklin, H.L.; Grivell, J.; Jones, K.L.; Clifton, P.M.; Horowitz, M.; Rayner, C.K. A whey/guar "preload" improves postprandial glycaemia and glycated haemoglobin levels in type 2 diabetes: A 12-week, single-blind, randomized, placebo-controlled trial. Diabetes Obes. Metab. 2019, 21, 930-938. [CrossRef] [PubMed]

106. Ma, J.; Jesudason, D.R.; Stevens, J.E.; Keogh, J.B.; Jones, K.L.; Clifton, P.M.; Horowitz, M.; Rayner, C.K. Sustained effects of a protein 'preload'on glycaemia and gastric emptying over 4 weeks in patients with type 2 diabetes: A randomized clinical trial. Diabetes Res. Clin. Pract. 2015, 108, e31-e34. [CrossRef] [PubMed] 
107. Holt, S.; Carter, D.; Tothill, P.; Heading, R.; Prescott, L. Effect of gel fibre on gastric emptying and absorption of glucose and paracetamol. Lancet 1979, 313, 636-639. [CrossRef]

108. French, S.J.; Read, N.W. Effect of guar gum on hunger and satiety after meals of differing fat content: Relationship with gastric emptying. Am. J. Clin. Nutr. 1994, 59, 87-91. [CrossRef] [PubMed]

109. Benini, L.; Castellani, G.; Brighenti, F.; Heaton, K.W.; Brentegani, M.T.; Casiraghi, M.C.; Sembenini, C.; Pellegrini, N.; Fioretta, A.; Minniti, G. Gastric emptying of a solid meal is accelerated by the removal of dietary fibre naturally present in food. Gut 1995, 36, 825-830. [CrossRef] [PubMed]

110. Rolls, B.J.; Fedoroff, I.C.; Guthrie, J.F. Gender differences in eating behavior and body weight regulation. Health Psychol. 1991, 10, 133-142. [CrossRef] [PubMed]

111. Giezenaar, C.; Luscombe-Marsh, N.D.; Hutchison, A.T.; Lange, K.; Hausken, T.; Jones, K.L.; Horowitz, M.; Chapman, I.; Soenen, S. Effect of gender on the acute effects of whey protein ingestion on energy intake, appetite, gastric emptying and gut hormone responses in healthy young adults. Nutr. Diabetes 2018, 8, 1-12. [CrossRef]

112. Giezenaar, C.; Lange, K.; Hausken, T.; Jones, K.L.; Horowitz, M.; Chapman, I.; Soenen, S. Effects of Age on Acute Appetite-Related Responses to Whey-Protein Drinks, Including Energy Intake, Gastric Emptying, Blood Glucose, and Plasma Gut Hormone Concentrations-A Randomized Controlled Trial. Nutrients 2020, 12, 1008. [CrossRef]

113. Gonenne, J.; Esfandyari, T.; Camilleri, M.; Burton, D.D.; Stephens, D.A.; Baxter, K.L.; Zinsmeister, A.R.; Bharucha, A.E. Effect of female sex hormone supplementation and withdrawal on gastrointestinal and colonic transit in postmenopausal women. Neurogastroenterol. Motil. 2006, 18, 911-918. [CrossRef]

114. Hellmig, S.; Von Schöning, F.; Gadow, C.; Katsoulis, S.; Hedderich, J.; Fölsch, U.R.; Stüber, E. Gastric emptying time of fluids and solids in healthy subjects determined by $13 \mathrm{C}$ breath tests: Influence of age, sex and body mass index. J. Gastroenterol. Hepatol. 2006, 21, 1832-1838. [CrossRef]

115. Moore, J.G.; Tweedy, C.; Christian, P.E.; Datz, F.L. Effect of age on gastric emptying of liquid-solid meals in man. Dig. Dis. Sci. 1983, 28, 340-344. [CrossRef] [PubMed]

116. Weindruch, R.; Sohal, R.S. Caloric Intake and Aging. N. Engl. J. Med. 1997, 337, 986-994. [CrossRef]

117. Schwartz, J.G.; Mcmahan, C.A.; Green, G.M.; Phillips, W.T. Gastric emptying in Mexican Americans compared to non-Hispanic whites. Dig. Dis. Sci. 1995, 40, 624-630. [CrossRef] [PubMed]

118. Schwartz, J.; Salman, U.; Mcmahan, C.; Phillips, W. Gastric emptying of beer in Mexican-Americans compared with non-hispanic whites. Metabolism 1996, 45, 1174-1178. [CrossRef]

119. Cohen, M.P.; Stern, E.; Rusecki, Y.; Zeidler, A. High prevalence of diabetes in young adult Ethiopian immigrants to Israel. Diabetes 1988, 37, 824-828. [CrossRef]

120. Howard, B.V.; Bogardus, C.; Ravussin, E.; E Foley, J.; Lillioja, S.; Mott, D.M.; Bennett, P.H.; Knowler, W.C. Studies of the etiology of obesity in Pima Indians. Am. J. Clin. Nutr. 1991, 53, 1577S-1585S. [CrossRef] [PubMed]

121. Wang, X.; Xie, C.; Marathe, C.S.; Malbert, C.-H.; Horowitz, M.; Jones, K.L.; Rayner, C.K.; Sun, Z.; Wu, T. Disparities in gastric emptying and postprandial glycaemia between Han Chinese and Caucasians with type 2 diabetes. Diabetes Res. Clin. Pract. 2020, 159, 107951. [CrossRef] [PubMed]

122. Carrio, I.; Estorch, M.; Serra-Grima, R.; Ginjaume, M.; Notivol, R.; Calabuig, R.; Vilardell, F. Gastric emptying in marathon runners. Gut 1989, 30, 152-155. [CrossRef] [PubMed]

123. Davis, J.; Camilleri, M.; Eckert, D.; Burton, D.; Joyner, M.; Acosta, A. Physical activity is associated with accelerated gastric emptying and increased ghrelin in obesity. Neurogastroenterol. Motil. 2020, 32, e13879. [CrossRef] [PubMed]

124. Horner, K.M.; Schubert, M.M.; Desbrow, B.; Byrne, N.M.; King, N.A. Acute Exercise and Gastric Emptying: A Meta-Analysis and Implications for Appetite Control. Sports Med. 2015, 45, 659-678. [CrossRef] [PubMed]

125. Mateos, A.M.C.; Roa-Colomo, A.; Vílchez, B.V. Changes in gastric emptying of digestible solids in professional cyclists: Relationship with exercise intensity. Revista Española de Enfermedades Digestivas 2020. [CrossRef]

126. Delgado-Aros, S.; Camilleri, M.; Castillo, E.J.; Cremonini, F.; Stephens, D.; Ferber, I.; Baxter, K.; Burton, D.; Zinsmeister, A.R. Effect of Gastric Volume or Emptying on Meal-Related Symptoms After Liquid Nutrients in Obesity: A Pharmacologic Study. Clin. Gastroenterol. Hepatol. 2005, 3, 997-1006. [CrossRef]

127. Roque, M.I.V.; Camilleri, M.; Stephens, D.A.; Jensen, M.D.; Burton, D.D.; Baxter, K.L.; Zinsmeister, A.R. Gastric Sensorimotor Functions and Hormone Profile in Normal Weight, Overweight, and Obese People. Gastroenterology 2006, 131, 1717-1724. [CrossRef] [PubMed]

128. Wright, R.A.; Krinsky, S.; Fleeman, C.; Trujillo, J.; Teague, E. Gastric emptying and obesity. Gastroenterology 1983, 84, 747-751. [CrossRef]

129. Tosetti, C.; Corinaldesi, R.; Stanghellini, V.; Pasquali, R.; Corbelli, C.; Zoccoli, G.; Di Febo, G.; Monetti, N.; Barbara, L. Gastric emptying of solids in morbid obesity. Int. J. Obes. Relat. Metab. Disord. J. Int. Assoc. Study Obes. 1996, $20,200$.

130. Maddox, A.; Horowitz, M.; Wishart, J.; Collins, P. Gastric and Oesophageal Emptying in Obesity. Scand. J. Gastroenterol. 1989, 24, 593-598. [CrossRef] [PubMed]

131. Jackson, S.J.; Leahy, F.E.; McGowan, A.A.; Bluck, L.J.C.; Coward, W.A.; Jebb, S.A. Delayed gastric emptying in the obese: An assessment using the non-invasive 13C-octanoic acid breath test. Diabetes Obes. Metab. 2004, 6, 264-270. [CrossRef]

132. Horowitz, M.; Collins, P.J.; Cook, D.J.; E Harding, P.; Shearman, D.J. Abnormalities of gastric emptying in obese patients. Int. J. Obes. 1983, 7, 415-421. [CrossRef] 
133. Phillips, L.K.; Deane, A.M.; Jones, K.L.; Rayner, C.K.; Horowitz, M. Gastric emptying and glycaemia in health and diabetes mellitus. Nat. Rev. Endocrinol. 2015, 11, 112-128. [CrossRef]

134. Parkman, H.P.; Urbain, J.-L.C.; Knight, L.C.; Brown, K.L.; Trate, D.M.; A Miller, M.; Maurer, A.H.; Fisher, R.S. Effect of gastric acid suppressants on human gastric motility. Gut 1998, 42, 243-250. [CrossRef] [PubMed]

135. Cunningham, K.M.; Daly, J.; Horowitz, M.; Read, N.W. Gastrointestinal adaptation to diets of differing fat composition in human volunteers. Gut 1991, 32, 483-486. [CrossRef] [PubMed]

136. Miller, G.; Palmer, K.R.; Smith, B.; Ferrington, C.; Merrick, M.V. Smoking delays gastric emptying of solids. Gut 1989, 30, 50-53. [CrossRef] [PubMed]

137. Johansson, C.; Ekelund, K. Relation between body weight and the gastric and intestinal handling of an oral caloric load. Gut 1976, 17, 456-462. [CrossRef]

138. Pajot, G.; Camilleri, M.; Calderon, G.; Davis, J.; Eckert, D.; Burton, D.; Acosta, A. Association between gastrointestinal phenotypes and weight gain in younger adults: A prospective 4-year cohort study. Int. J. Obes. 2020, 44, 2472-2478. [CrossRef] [PubMed]

139. Geliebter, A.; Schachter, S.; Lohmann-Walter, C.; Feldman, H.; A Hashim, S. Reduced stomach capacity in obese subjects after dieting. Am. J. Clin. Nutr. 1996, 63, 170-173. [CrossRef]

140. Granström, L.; Backman, L. Stomach distension in extremely obese and in normal subjects. Acta Chir. Scand. 1985, 151, 367-370.

141. Geliebter, A. Gastric distension and gastric capacity in relation to food intake in humans. Physiol. Behav. 1988, 44, 665-668. [CrossRef]

142. Bagger, J.I.; Holst, J.J.; Hartmann, B.; Andersen, B.; Knop, F.K.; Vilsbøll, T. Effect of Oxyntomodulin, Glucagon, GLP-1, and Combined Glucagon +GLP-1 Infusion on Food Intake, Appetite, and Resting Energy Expenditure. J. Clin. Endocrinol. Metab. 2015, 100, 4541-4552. [CrossRef]

143. Schjoldager, B.; Mortensen, P.E.; Myhre, J.; Christiansen, J.; Holst, J.J. Oxyntomodulin from distal gut. Dig. Dis. Sci. 1989, 34, 1411-1419. [CrossRef] [PubMed]

144. Naslund, E.; Grybäck, P.; Bäckman, L.; Jacobsson, H.; Holst, J.J.; Theodorsson, H.E.; Hellstrom, P.M.; Juul, J. Distal Small Bowel Hormones (Correlation with Fasting Antroduodenal Motility and Gastric Emptying). Dig. Dis. Sci. 1998, 43, 945-952. [CrossRef]

145. Bonazzi, P.; Petrelli, M.D.; Lorenzini, I.; Peruzzi, E.; Nicolai, A.; Galeazzi, R. Gastric emptying and intragastric balloon in obese patients. Eur. Rev. Med Pharmacol. Sci. 2006, 9, 15-21.

146. Reis, G.M.F.; Malheiros, C.A.; Savassi-Rocha, P.R.; Júnior, O.L.C.; Thuler, F.R.; Faria, M.L.; Filho, V.G. Gastric Emptying and Food Tolerance Following Banded and Non-banded Roux-en-Y Gastric Bypass. Obes. Surg. 2018, 29, 560-568. [CrossRef] [PubMed]

147. Hutson, W.R.; Wald, A. Obesity and weight reduction do not influence gastric emptying and antral motility. Am. J. Gastroenterol. $1993,88,88$.

148. Torra, S.; Ilzarbe, L.; Malagelada, J.R.; Negre, M.; Mestre-Fusco, A.; Aguadé-Bruix, S.; Florensa, E.; Suñé, P.; Gras, B.; Hernandez, J.J.; et al. Meal size can be decreased in obese subjects through pharmacological acceleration of gastric emptying (The OBERYTH trial). Int. J. Obes. 2010, 35, 829-837. [CrossRef] [PubMed]

149. Horowitz, M.; Cook, D.J.; Collins, P.J.; Harding, P.E.; Hooper, M.J.; Walsh, J.F.; Shearman, D.J.C. Measurement of gastric emptying after gastric bypass surgery using radionuclides. BJS 1982, 69, 655-657. [CrossRef] [PubMed]

150. Morínigo, R.; Moizé, V.; Musri, M.; Lacy, A.M.; Navarro, S.; Marín, J.L.; Delgado, S.; Casamitjana, R.; Vidal, J. Glucagon-Like Peptide-1, Peptide YY, Hunger, and Satiety after Gastric Bypass Surgery in Morbidly Obese Subjects. J. Clin. Endocrinol. Metab. 2006, 91, 1735-1740. [CrossRef] [PubMed]

151. Falkén, Y.; Hellström, P.M.; Holst, J.J.; Näslund, E. Changes in glucose homeostasis after Roux-en-Y gastric bypass surgery for obesity at day three, two months, and one year after surgery: Role of gut peptides. J. Clin. Endocrinol. Metab. 2011, 96, 2227-2235. [CrossRef]

152. Shah, S.; Shah, P.; Todkar, J.; Gagner, M.; Sonar, S.; Solav, S. Prospective controlled study of effect of laparoscopic sleeve gastrectomy on small bowel transit time and gastric emptying half-time in morbidly obese patients with type 2 diabetes mellitus. Surg. Obes. Relat. Dis. 2010, 6, 152-157. [CrossRef]

153. Gómez, V.; Woodman, G.; Abu Dayyeh, B.K. Delayed gastric emptying as a proposed mechanism of action during intragastric balloon therapy: Results of a prospective study. Obesity 2016, 24, 1849-1853. [CrossRef] [PubMed]

154. Friedrichsen, M.; Breitschaft, A.; Tadayon, S.; Wizert, A.; Skovgaard, D. The effect of semaglutide 2.4 mg once weekly on energy intake, appetite, control of eating and gastric emptying in subjects with obesity. Diabetes Obes. Metab. 2021, 23, 754-762. [CrossRef]

155. Lopez-Nava, G.; Jaruvongvanich, V.; Storm, A.C.; Maselli, D.B.; Bautista-Castaño, I.; Vargas, E.J.; Matar, R.; Acosta, A.; Abu Dayyeh, B.K. Personalization of Endoscopic Bariatric and Metabolic Therapies Based on Physiology: A Prospective Feasibility Study with a Single Fluid-Filled Intragastric Balloon. Obes. Surg. 2020, 30, 3347-3353. [CrossRef] [PubMed]

156. Locke, A.E.; Kahali, B.; Berndt, S.I.; Justice, A.E.; Pers, T.H.; Day, F.R.; Powell, C.; Vedantam, S.; Buchkovich, M.L.; Yang, J.; et al. Genetic studies of body mass index yield new insights for obesity biology. Nature 2015, 518, 197-206. [CrossRef]

157. Loos, R.J. Genetic determinants of common obesity and their value in prediction. Best Pr. Res. Clin. Endocrinol. Metab. 2012, 26, 211-226. [CrossRef] [PubMed]

158. Pulit, S.L.; Stoneman, C.; Morris, A.P.; Wood, A.R.; Glastonbury, C.A.; Tyrrell, J.; Yengo, L.; Ferreira, T.; Marouli, E.; Ji, Y.; et al. Meta-analysis of genome-wide association studies for body fat distribution in 694649 individuals of European ancestry. Hum. Mol. Genet. 2019, 28, 166-174. [CrossRef] [PubMed]

159. Farooqi, I.S.; O’Rahilly, S. Monogenic Obesity in Humans. Annu. Rev. Med. 2005, 56, 443-458. [CrossRef] [PubMed] 
160. Haqq, A.M.; Farooqi, I.S.; O’Rahilly, S.; Stadler, D.D.; Rosenfeld, R.G.; Pratt, K.L.; LaFranchi, S.H.; Purnell, J.Q. Serum Ghrelin Levels Are Inversely Correlated with Body Mass Index, Age, and Insulin Concentrations in Normal Children and Are Markedly Increased in Prader-Willi Syndrome. J. Clin. Endocrinol. Metab. 2003, 88, 174-178. [CrossRef] [PubMed]

161. Arenz, T.; Schwarzer, A.; Pfluger, T.; Koletzko, S.; Schmidt, H. Delayed gastric emptying in patients with Prader Willi Syndrome. J. Pediatr. Endocrinol. Metab. 2010, 23, 867-871. [CrossRef] [PubMed]

162. Choe, Y.H.; Jin, D.-K.; Kim, S.E.; Song, S.Y.; Paik, K.H.; Park, H.Y.; Oh, Y.J.; Kim, A.H.; Kim, J.S.; Kim, C.W.; et al. Hyperghrelinemia Does Not Accelerate Gastric Emptying in Prader-Willi Syndrome Patients. J. Clin. Endocrinol. Metab. 2005, 90, 3367-3370. [CrossRef]

163. Yau, A.M.W.; McLaughlin, J.; Maughan, R.J.; Gilmore, W.; Ashworth, J.J.; Evans, G.H. A Pilot Study Investigating the Influence of Glucagon-Like Peptide-1 Receptor Single Nucleotide Polymorphisms on Gastric Emptying Rate in Caucasian Men. Front. Physiol. 2018, 9, 1331. [CrossRef]

164. Acosta, A.; Camilleri, M.; Shin, A.; Carlson, P.; Burton, D.; O’Neill, J.; Eckert, D.; Zinsmeister, A.R. Association of melanocortin 4 receptor gene variation with satiation and gastric emptying in overweight and obese adults. Genes Nutr. 2014, 9, 384. [CrossRef] [PubMed]

165. Cremonini, F.; Camilleri, M.; McKinzie, S.; Carlson, P.; E Camilleri, C.; Burton, D.D.; Thomforde, G.M.; Urrutia, R.; Zinsmeister, A.R. Effect of CCK-1 Antagonist, Dexloxiglumide, in Female Patients with Irritable Bowel Syndrome: A Pharmacodynamic and Pharmacogenomic Study. Am. J. Gastroenterol. 2005, 100, 652-663. [CrossRef] [PubMed]

166. Anderson, B.; Carlson, P.; Laurenti, M.; Vella, A.; Camilleri, M.; Desai, A.; Feuerhak, K.; Bharucha, A.E. Association between allelic variants in the glucagon-like peptide 1 and cholecystokinin receptor genes with gastric emptying and glucose tolerance. Neurogastroenterol. Motil. 2020, 32, e13724. [CrossRef] [PubMed]

167. Chedid, V.; Vijayvargiya, P.; Carlson, P.; Van Malderen, K.; Acosta, A.; Zinsmeister, A.; Camilleri, M. Allelic variant in the glucagon-like peptide 1 receptor gene associated with greater effect of liraglutide and exenatide on gastric emptying: A pilot pharmacogenetics study. Neurogastroenterol. Motil. 2018, 30, e13313. [CrossRef] [PubMed]

168. Ryan, D.H.; Yockey, S.R. Weight Loss and Improvement in Comorbidity: Differences at 5\%, 10\%, 15\%, and Over. Curr. Obes. Rep. 2017, 6, 187-194. [CrossRef]

169. Wing, R.R.; Lang, W.; Wadden, T.A.; Safford, M.; Knowler, W.C.; Bertoni, A.G.; Hill, J.O.; Brancati, F.L.; Peters, A.; Wagenknecht, L.; et al. Benefits of Modest Weight Loss in Improving Cardiovascular Risk Factors in Overweight and Obese Individuals With Type 2 Diabetes. Diabetes Care 2011, 34, 1481-1486. [CrossRef]

170. A King, N.; Hopkins, M.; Caudwell, P.; Stubbs, R.J.; E Blundell, J. Beneficial effects of exercise: Shifting the focus from body weight to other markers of health. Br. J. Sports Med. 2009, 43, 924-927. [CrossRef] [PubMed]

171. Horowitz, M.; Maddox, A.; Wishart, J.; Vernon-Roberts, J.; Chatterton, B.; Shearman, D. Effect of dexfenfluramine on gastric emptying of a mixed solid-liquid meal in obese subjects. Br. J. Nutr. 1990, 63, 447-455. [CrossRef]

172. Pilitsi, E.; Farr, O.M.; Polyzos, S.A.; Perakakis, N.; Nolen-Doerr, E.; Papathanasiou, A.-E.; Mantzoros, C.S. Pharmacotherapy of obesity: Available medications and drugs under investigation. Metabolism 2019, 92, 170-192. [CrossRef] [PubMed]

173. Czepiel, K.S.; Perez, N.P.; Reyes, K.J.C.; Sabharwal, S.; Stanford, F.C. Pharmacotherapy for the Treatment of Overweight and Obesity in Children, Adolescents, and Young Adults in a Large Health System in the US. Front. Endocrinol. 2020, 11, 290. [CrossRef] [PubMed]

174. Kelly, A.S.; Auerbach, P.; Barrientos-Perez, M.; Gies, I.; Hale, P.M.; Marcus, C.; Mastrandrea, L.D.; Prabhu, N.; Arslanian, S. A Randomized, Controlled Trial of Liraglutide for Adolescents with Obesity. N. Engl. J. Med. 2020, 382, 2117-2128. [CrossRef] [PubMed]

175. Schwizer, W.; Asal, K.; Kreiss, C.; Mettraux, C.; Borovicka, J.; Remy, B.; Guzelhan, C.; Hartmann, D.; Fried, M. Role of lipase in the regulation of upper gastrointestinal function in humans. Am. J. Physiol. Content 1997, 273, G612-G620. [CrossRef] [PubMed]

176. Borovicka, J.; Schwizer, W.; Guttmann, G.; Hartmann, D.; Kosinski, M.; Wastiel, C.; Bischof-Delaloye, A.; Fried, M. Role of lipase in the regulation of postprandial gastric acid secretion and emptying of fat in humans: A study with orlistat, a highly specific lipase inhibitor. Gut 2000, 46, 774-781. [CrossRef] [PubMed]

177. Pilichiewicz, A.; O’Donovan, D.; Feinle, C.; Lei, Y.; Wishart, J.M.; Bryant, L.; Meyer, J.H.; Horowitz, M.; Jones, K.L. Effect of Lipase Inhibition on Gastric Emptying of, and the Glycemic and Incretin Responses to, an Oil/Aqueous Drink in Type 2 Diabetes Mellitus. J. Clin. Endocrinol. Metab. 2003, 88, 3829-3834. [CrossRef] [PubMed]

178. O’Donovan, D.; Horowitz, M.; Russo, A.; Feinle-Bisset, C.; Murolo, N.; Gentilcore, D.; Wishart, J.M.; Morris, H.A.; Jones, K.L. Effects of lipase inhibition on gastric emptying of, and on the glycaemic, insulin and cardiovascular responses to, a high-fat/carbohydrate meal in type 2 diabetes. Diabetologia 2004, 47, 2208-2214. [CrossRef]

179. Mathus-Vliegen, E.M.H.; Leeuwen, M.L.V.I.-V.; Bennink, R.J. Influences of fat restriction and lipase inhibition on gastric emptying in obesity. Int. J. Obes. 2006, 30, 1203-1210. [CrossRef] [PubMed]

180. Flint, A.; Raben, A.; Ersbøll, A.; Holst, J.; Astrup, A. The effect of physiological levels of glucagon-like peptide-1 on appetite, gastric emptying, energy and substrate metabolism in obesity. Int. J. Obes. 2001, 25, 781-792. [CrossRef] [PubMed]

181. Clapper, J.R.; Athanacio, J.; Wittmer, C.; Griffin, P.S.; D'Souza, L.; Parkes, D.G.; Roth, J.D. Effects of amylin and bupropion/naltrexone on food intake and body weight are interactive in rodent models. Eur. J. Pharmacol. 2013, 698, 292-298. [CrossRef] 
182. Acosta, A.; Camilleri, M.; Burton, D.; O’Neill, J.; Eckert, D.; Carlson, P.; Zinsmeister, A.R. Exenatide in obesity with accelerated gastric emptying: A randomized, pharmacodynamics study. Physiol. Rep. 2015, 3, 12610. [CrossRef] [PubMed]

183. Blundell, J.; Finlayson, G.; Axelsen, M.; Flint, A.; Gibbons, C.; Kvist, T.; Hjerpsted, J.B. Effects of once-weekly semaglutide on appetite, energy intake, control of eating, food preference and body weight in subjects with obesity. Diabetes Obes. Metab. 2017, 19, 1242-1251. [CrossRef]

184. Hjerpsted, J.B.; Flint, A.; Brooks, A.; Axelsen, M.B.; Kvist, T.; Blundell, J. Semaglutide improves postprandial glucose and lipid metabolism, and delays first-hour gastric emptying in subjects with obesity. Diabetes Obes. Metab. 2017, 20, 610-619. [CrossRef] [PubMed]

185. Linnebjerg, H.; Park, S.; Kothare, P.A.; Trautmann, M.E.; Mace, K.; Fineman, M.; Wilding, I.; Nauck, M.; Horowitz, M. Effect of exenatide on gastric emptying and relationship to postprandial glycemia in type 2 diabetes. Regul. Pept. 2008, 151, 123-129. [CrossRef] [PubMed]

186. Jones, K.L.; Huynh, L.Q.; Hatzinikolas, S.; Rigda, R.S.; Phillips, L.K.; Pham, H.T.; Marathe, C.S.; Wu, T.; Malbert, C.H.; Stevens, J.E.; et al. Exenatide once weekly slows gastric emptying of solids and liquids in healthy, overweight people at steady-state concentrations. Diabetes, Obes. Metab. 2020, 22, 788-797. [CrossRef] [PubMed]

187. Maselli, D.B.; Camilleri, M. Effects of GLP-1 and Its Analogs on Gastric Physiology in Diabetes Mellitus and Obesity. Adv. Exp. Med. Biol. 2021, 1307, 171-192. [PubMed]

188. Horowitz, M.; Aroda, V.R.; Han, J.; Hardy, E.; Rayner, C.K. Upper and/or lower gastrointestinal adverse events with glucagon-like peptide-1 receptor agonists: Incidence and consequences. Diabetes Obes. Metab. 2017, 19, 672-681. [CrossRef] [PubMed]

189. Lingvay, I.; Hansen, T.; Macura, S.; Marre, M.; A Nauck, M.; De La Rosa, R.; Woo, V.; Yildirim, E.; Wilding, J. Superior weight loss with once-weekly semaglutide versus other glucagon-like peptide-1 receptor agonists is independent of gastrointestinal adverse events. BMJ Open Diabetes Res. Care 2020, 8, e001706. [CrossRef] [PubMed]

190. Dahl, K.; Brooks, A.; Almazedi, F.; Hoff, S.T.; Boschini, C.; Bækdal, T.A. Oral semaglutide improves postprandial glucose and lipid metabolism, and delays gastric emptying, in subjects with type 2 diabetes. Diabetes Obes. Metab. 2021. [CrossRef]

191. Holst, J.J. Incretin hormones and the satiation signal. Int. J. Obes. 2013, 37, 1161-1168. [CrossRef] [PubMed]

192. Farr, O.M.; Sofopoulos, M.; Tsoukas, M.A.; Dincer, F.; Thakkar, B.; Sahin-Efe, A.; Filippaios, A.; Bowers, J.; Srnka, A.; Gavrieli, A.; et al. GLP-1 receptors exist in the parietal cortex, hypothalamus and medulla of human brains and the GLP-1 analogue liraglutide alters brain activity related to highly desirable food cues in individuals with diabetes: A crossover, randomised, placebo-controlled trial. Diabetologia 2016, 59, 954-965. [CrossRef] [PubMed]

193. Jalleh, R.; Pham, H.; Marathe, C.S.; Wu, T.; Buttfield, M.D.; Hatzinikolas, S.; Malbert, C.H.; Rigda, R.S.; Lange, K.; Trahair L.G.; et al. Acute Effects of Lixisenatide on Energy Intake in Healthy Subjects and Patients with Type 2 Diabetes: Relationship to Gastric Emptying and Intragastric Distribution. Nutrients 2020, 12, 1962. [CrossRef]

194. Smith, S.R.; Aronne, L.J.; Burns, C.M.; Kesty, N.C.; Halseth, A.E.; Weyer, C. Sustained Weight Loss Following 12-Month Pramlintide Treatment as an Adjunct to Lifestyle Intervention in Obesity. Diabetes Care 2008, 31, 1816-1823. [CrossRef] [PubMed]

195. Nascimento, C.V.M.; Sinezia, C.; Sisnande, T.; Lima, L.M.T.; Lacativa, P.G. BZ043, a novel long-acting amylin analog, reduces gastric emptying, food intake, glycemia and insulin requirement in streptozotocin-induced diabetic rats. Peptides 2019, 114, 44-49. [CrossRef] [PubMed]

196. Batterham, R.L.; Cohen, M.A.; Ellis, S.M.; Le Roux, C.W.; Withers, D.J.; Frost, G.S.; Ghatei, M.A.; Bloom, S.R. Inhibition of Food Intake in Obese Subjects by Peptide YY3-36. N. Engl. J. Med. 2003, 349, 941-948. [CrossRef] [PubMed]

197. CllinicalTrials.gov. A Research Study of NNC0165-1562 and Semaglutide in People Who Are Overweight or Obese. 2020. Available online: https:/ / clinicaltrials.gov/ct2/show/NCT03574584 (accessed on 22 December 2020).

198. R Mattin, L.; J McIver, V.; Yau, A.M.W.; J James, L.; H Evans, G. A comparison of intermittent and continuous exercise bouts at different intensities on appetite and postprandial metabolic responses in healthy men. Nutrients 2020, 12, 2370. [CrossRef] [PubMed]

199. Witte, A.-B.; Grybäck, P.; Holst, J.J.; Hilsted, L.; Hellström, P.M.; Jacobsson, H.; Schmidt, P. Differential effect of PYY1-36 and PYY3-36 on gastric emptying in man. Regul. Pept. 2009, 158, 57-62. [CrossRef] [PubMed]

200. Izundegui, D.G.; Singh, S.; Acosta, A. Food intake regulation: Relevance to bariatric and metabolic endoscopic therapies. Tech. Innov. Gastrointest. Endosc. 2020, 22, 100-108. [CrossRef]

201. Mion, F.; Napoléon, B.; Roman, S.; Malvoisin, E.; Trepo, F.; Pujol, B.; Lefort, C.; Bory, R.-M. Effects of Intragastric Balloon on Gastric Emptying and Plasma Ghrelin Levels in Non-morbid Obese Patients. Obes. Surg. 2005, 15, 510-516. [CrossRef] [PubMed]

202. Su, H.-J.; Kao, C.-H.; Chen, W.-C.; Chang, T.-T.; Lin, C.-Y. Effect of Intragastric Balloon on Gastric Emptying Time in Humans for Weight Control. Clin. Nucl. Med. 2013, 38, 863-868. [CrossRef] [PubMed]

203. Vargas, E.J.; Bazerbachi, F.; Calderon, G.; Prokop, L.J.; Gomez, V.; Murad, M.H.; Acosta, A.; Camilleri, M.; Abu Dayyeh, B.K. Changes in Time of Gastric Emptying After Surgical and Endoscopic Bariatrics and Weight Loss: A Systematic Review and Meta-Analysis. Clin. Gastroenterol. Hepatol. 2020, 18, 57-68.e5. [CrossRef]

204. Abu Dayyeh, B.K.; Rajan, E.; Gostout, C.J. Endoscopic sleeve gastroplasty: A potential endoscopic alternative to surgical sleeve gastrectomy for treatment of obesity. Gastrointest. Endosc. 2013, 78, 530-535. [CrossRef] [PubMed]

205. James, A.N.; Ryan, J.P.; Parkman, H.P. Inhibitory effects of botulinum toxin on pyloric and antral smooth muscle. Am. J. Physiol. Liver Physiol. 2003, 285, G291-G297. [CrossRef] [PubMed] 
206. Topazian, M.; Camilleri, M.; De La Mora-Levy, J.; Enders, F.B.; Foxx-Orenstein, A.E.; Levy, M.J.; Nehra, V.; Talley, N.J. Endoscopic ultrasound-guided gastric botulinum toxin injections in obese subjects: A pilot study. Obes. Surg. 2008, 18, 401-407. [CrossRef] [PubMed]

207. Topazian, M.; Camilleri, M.; Enders, F.T.; Clain, J.E.; Gleeson, F.C.; Levy, M.J.; Rajan, E.; Nehra, V.; Dierkhising, R.A.; CollazoClavell, M.L.; et al. Gastric antral injections of botulinum toxin delay gastric emptying but do not reduce body weight. Clin. Gastroenterol. Hepatol. 2013, 11, 145-150.e1. [CrossRef] [PubMed]

208. Trostler, N.; Mann, A.; Zilberbush, N.; Avinoach, E.; Charuzi, I. Weight Loss and Food Intake 18 Months following Vertical Banded Gastroplasty or Gastric Bypass for Severe Obesity. Obes. Surg. 1995, 5, 39-51. [CrossRef] [PubMed]

209. Cummings, D.E.; Weigle, D.S.; Frayo, R.S.; Breen, P.A.; Ma, M.K.; Dellinger, E.P.; Purnell, J.Q. Plasma Ghrelin Levels after Diet-Induced Weight Loss or Gastric Bypass Surgery. N. Engl. J. Med. 2002, 346, 1623-1630. [CrossRef] [PubMed]

210. Le Roux, C.W.; Aylwin, S.J.B.; Batterham, R.L.; Borg, C.M.; Coyle, F.; Prasad, V.; Shurey, S.; Ghatei, M.A.; Patel, A.G.; Bloom, S.R. Gut Hormone Profiles Following Bariatric Surgery Favor an Anorectic State, Facilitate Weight Loss, and Improve Metabolic Parameters. Ann. Surg. 2006, 243, 108-114. [CrossRef] [PubMed]

211. Gu, L.; Lin, K.; Du, N.; Ng, D.M.; Lou, D.; Chen, P. Differences in the effects of laparoscopic sleeve gastrectomy and laparoscopic Roux-en-Y gastric bypass on gut hormones: Systematic and meta-analysis. Surg. Obes. Relat. Dis. 2021, 17, 444-455. [CrossRef]

212. Yehoshua, R.T.; Eidelman, L.A.; Stein, M.; Fichman, S.; Mazor, A.; Chen, J.; Bernstine, H.; Singer, P.; Dickman, R.; Shikora, S.A.; et al. Laparoscopic Sleeve Gastrectomy_Volume and Pressure Assessment. Obes. Surg. 2008, 18, 1083-1088. [CrossRef] [PubMed]

213. Fiorillo, C.; Quero, G.; Dallemagne, B.; Curcic, J.; Fox, M.; Perretta, S. Effects of Laparoscopic Sleeve Gastrectomy on Gastric Structure and Function Documented by Magnetic Resonance Imaging Are Strongly Associated with Post-operative Weight Loss and Quality of Life: A Prospective Study. Obes. Surg. 2020, 30, 1-10. [CrossRef] [PubMed]

214. Garay, M.; Balagué, C.; Rodríguez-Otero, C.; Gonzalo, B.; Domenech, A.; Pernas, J.C.; Gich, I.J.; Miñambres, I.; Fernández-Ananín, S.; Targarona, E.M. Influence of antrum size on gastric emptying and weight-loss outcomes after laparoscopic sleeve gastrectomy (preliminary analysis of a randomized trial). Surg. Endosc. 2018, 32, 2739-2745. [CrossRef] [PubMed]

215. Mccarty, T.R.; Jirapinyo, P.; Thompson, C.C. 1128 Effect of Sleeve Gastrectomy on Ghrelin, GLP-1, PYY, and GIP Gut Hormones: A Systematic Review and Meta-Analysis. Am. J. Gastroenterol. 2019, 114, S633-S634. [CrossRef]

216. Wittgrove, A.C.; Clark, G.W. Laparoscopic Gastric Bypass, Roux en-Y—500 Patients: Technique and Results, with 3-60 month follow-up. Obes. Surg. 2000, 10, 233-239. [CrossRef] [PubMed]

217. Xu, H.-C.; Pang, Y.-C.; Chen, J.-W.; Cao, J.-Y.; Sheng, Z.; Yuan, J.-H.; Wang, R.; Zhang, C.-S.; Wang, L.-X.; Dong, J. Systematic Review and Meta-analysis of the Change in Ghrelin Levels After Roux-en-Y Gastric Bypass. Obes. Surg. 2019, $29,1343-1351$. [CrossRef] [PubMed]

218. Akkary, E.; Sidani, S.; Boonsiri, J.; Yu, S.; Dziura, J.; Duffy, A.J.; Bell, R.L. The paradox of the pouch: Prompt emptying predicts improved weight loss after laparoscopic Roux-Y gastric bypass. Surg. Endosc. 2008, 23, 790-794. [CrossRef] [PubMed]

219. Deden, L.N.; Cooiman, M.I.; Aarts, E.O.; Janssen, I.M.; Gotthardt, M.; Hendrickx, B.W.; Berends, F.J. Gastric pouch emptying of solid food in patients with successful and unsuccessful weight loss after Roux-en-Y gastric bypass surgery. Surg. Obes. Relat. Dis. 2017, 13, 1840-1846. [CrossRef] [PubMed]

220. E Cummings, D. Endocrine mechanisms mediating remission of diabetes after gastric bypass surgery. Int. J. Obes. 2009, 33, S33-S40. [CrossRef] [PubMed]

221. Nguyen, N.Q.; Debreceni, T.L.; Burgstad, C.M.; Wishart, J.M.; Bellon, M.; Rayner, C.K.; Wittert, G.A.; Horowitz, M. Effects of Posture and Meal Volume on Gastric Emptying, Intestinal Transit, Oral Glucose Tolerance, Blood Pressure and Gastrointestinal Symptoms After Roux-en-Y Gastric Bypass. Obes. Surg. 2014, 25, 1392-1400. [CrossRef] [PubMed]

222. Miras, A.D.; Kamocka, A.; Pérez-Pevida, B.; Purkayastha, S.; Moorthy, K.; Patel, A.; Chahal, H.; Frost, G.; Bassett, P.; CastagnettoGissey, L.; et al. The Effect of Standard Versus Longer Intestinal Bypass on GLP-1 Regulation and Glucose Metabolism in Patients With Type 2 Diabetes Undergoing Roux-en-Y Gastric Bypass: The Long-Limb Study. Diabetes Care 2020, dc200762. [CrossRef] [PubMed]

223. Verdich, C.; Madsen, J.L.; Toubro, S.; Buemann, B.; Holst, J.; Astrup, A. Effect of obesity and major weight reduction on gastric emptying. Int. J. Obes. 2000, 24, 899-905. [CrossRef] [PubMed]

224. Kadouh, H.; Chedid, V.; Halawi, H.; Burton, D.D.; Clark, M.M.; Khemani, D.; Vella, A.; Acosta, A.; Camilleri, M. GLP-1 Analog Modulates Appetite, Taste Preference, Gut Hormones, and Regional Body Fat Stores in Adults with Obesity. J. Clin. Endocrinol. Metab. 2019, 105, 1552-1563. [CrossRef] [PubMed]

225. Meier, J.J.; Rosenstock, J.; Hincelin-Méry, A.; Roy-Duval, C.; Delfolie, A.; Coester, H.-V.; Menge, B.A.; Forst, T.; Kapitza, C. Contrasting Effects of Lixisenatide and Liraglutide on Postprandial Glycemic Control, Gastric Emptying, and Safety Parameters in Patients With Type 2 Diabetes on Optimized Insulin Glargine With or Without Metformin: A Randomized, Open-Label Trial. Diabetes Care 2015, 38, 1263-1273. [CrossRef] [PubMed]

226. Yamada, Y.; Senda, M.; Naito, Y.; Tamura, M.; Watanabe, D.; Shuto, Y.; Urita, Y. Reduction of postprandial glucose by lixisenatide vs sitagliptin treatment in J apanese patients with type 2 diabetes on background insulin glargine: A randomized phase IV study (NEXTAGE Study). Diabetes, Obes. Metab. 2017, 19, 1252-1259. [CrossRef] [PubMed] 
227. Whyte, M.B.; Shojaee-Moradie, F.; E Sharaf, S.; Jackson, N.C.; Fielding, B.; Hovorka, R.; Mendis, J.; Russell-Jones, D.; Umpleby, A.M. Lixisenatide Reduces Chylomicron Triacylglycerol by Increased Clearance. J. Clin. Endocrinol. Metab. 2019, 104, 359-368. [CrossRef] [PubMed]

228. Rayner, C.K.; Watson, L.E.; Phillips, L.K.; Lange, K.; Bound, M.J.; Grivell, J.; Wu, T.; Jones, K.L.; Horowitz, M.; Ferrannini, E.; et al. Effects of Sustained Treatment With Lixisenatide on Gastric Emptying and Postprandial Glucose Metabolism in Type 2 Diabetes: A Randomized Controlled Trial. Diabetes Care 2020, 43, 1813-1821. [CrossRef] [PubMed]

229. Velchik, M.G.; Kramer, F.M.; Stunkard, A.J.; Alavi, A. Effect of the Garren-Edwards gastric bubble on gastric emptying. J. Nucl. Med. 1989, 30, 692-696.

230. Barrichello, S.; Badurdeen, D.; Hedjoudje, A.; Neto, M.G.; Yance, R.; Veinert, A.; Fayad, L.; Simsek, C.; Grecco, E.; De Souza, T.F.; et al. The Effect of the Intra-gastric Balloon on Gastric Emptying and the DeMeester Score. Obes. Surg. 2019, 30, 38-45. [CrossRef] [PubMed]

231. Hedberg, J.; Hedenström, H.; Karlsson, F.A.; Edén-Engström, B.; Sundbom, M. Gastric Emptying and Postprandial PYY Response After Biliopancreatic Diversion with Duodenal Switch. Obes. Surg. 2010, 21, 609-615. [CrossRef]

232. De Jong, J.R.; Van Ramshorst, B.; Gooszen, H.G.; Smout, A.J.P.M.; Buul, M.M.C.T.-V. Weight Loss after Laparoscopic Adjustable Gastric Banding is not Caused by Altered Gastric Emptying. Obes. Surg. 2008, 19, 287-292. [CrossRef]

233. Näslund, I.; Beckman, K.-W. Gastric Emptying Rate after Gastric Bypass and Gastroplasty. Scand. J. Gastroenterol. 1987, 22, 193-201. [CrossRef] [PubMed]

234. Melissas, J.; Koukouraki, S.; Askoxylakis, J.; Stathaki, M.; Daskalakis, M.; Perisinakis, K.; Karkavitsas, N. Sleeve gastrectomy-A restrictive procedure? Obes. Surg. 2007, 17, 57. [CrossRef] [PubMed]

235. Bernstine, H.; Tzioni-Yehoshua, R.; Groshar, D.; Beglaibter, N.; Shikora, S.; Rosenthal, R.J.; Rubin, M. Gastric Emptying is not Affected by Sleeve Gastrectomy-Scintigraphic Evaluation of Gastric Emptying after Sleeve Gastrectomy without Removal of the Gastric Antrum. Obes. Surg. 2008, 19, 293-298. [CrossRef] [PubMed]

236. Braghetto, I.; DaVanzo, C.; Korn, O.; Csendes, A.; Valladares, H.; Herrera, E.; Gonzalez, P.; Papapietro, K. Scintigraphic Evaluation of Gastric Emptying in Obese Patients Submitted to Sleeve Gastrectomy Compared to Normal Subjects. Obes. Surg. 2009, 19, 1515-1521. [CrossRef] [PubMed]

237. Michalsky, D.; Dvorak, P.; Belacek, J.; Kasalicky, M. Radical Resection of the Pyloric Antrum and Its Effect on Gastric Emptying After Sleeve Gastrectomy. Obes. Surg. 2013, 23, 567-573. [CrossRef]

238. Pilone, V.; Tramontano, S.; Di Micco, R.; Monda, A.; Hasani, A.; Izzo, G.; Vitiello, A.; Caprio, M.; Cuocolo, A.; Forestieri, P. Gastric emptying after sleeve gastrectomy: Statistical evidence of a controlled prospective study with gastric scintigraphy (180 visite). Minerva Chir. 2013, 68, 385-392. [PubMed]

239. Melissas, J.; Leventi, A.; Klinaki, I.; Perisinakis, K.; Koukouraki, S.; de Bree, E.; Karkavitsas, N. Alterations of global gastrointestinal motility after sleeve gastrectomy: A prospective study. Ann. Surg. 2013, 258, 976-982. [CrossRef] [PubMed]

240. Kandeel, A.A.; Sarhan, M.D.; Hegazy, T.; Mahmoud, M.M.; Ali, M.H. Comparative assessment of gastric emptying in obese patients before and after laparoscopic sleeve gastrectomy using radionuclide scintigraphy. Nucl. Med. Commun. 2015, 36, 854-862. [CrossRef]

241. Burgerhart, J.S.; Van Rutte, P.W.J.; Edelbroek, M.A.L.; Wyndaele, D.N.J.; Smulders, J.F.; Van De Meeberg, P.C.; Siersema, P.D.; Smout, A.J.P.M. Association Between Postprandial Symptoms and Gastric Emptying After Sleeve Gastrectomy. Obes. Surg. 2014, 25, 209-214. [CrossRef] [PubMed]

242. Vigneshwaran, B.; Wahal, A.; Aggarwal, S.; Priyadarshini, P.; Bhattacharjee, H.; Khadgawat, R.; Yadav, R. Impact of Sleeve Gastrectomy on Type 2 Diabetes Mellitus, Gastric Emptying Time, Glucagon-Like Peptide 1 (GLP-1), Ghrelin and Leptin in Non-morbidly Obese Subjects with BMI 30-35.0 kg/m²: A Prospective Study. Obes. Surg. 2016, 26, 2817-2823. [CrossRef] [PubMed]

243. Vives, M.; Molina, A.; Danús, M.; Rebenaque, E.; Blanco, S.; París, M.; Sánchez, A.; Sabench, F.; Del Castillo, D. Analysis of Gastric Physiology After Laparoscopic Sleeve Gastrectomy (LSG) With or Without Antral Preservation in Relation to Metabolic Response: A Randomised Study. Obes. Surg. 2017, 27, 2836-2844. [CrossRef] [PubMed]

244. Sista, F.; Abruzzese, V.; Clementi, M.; Carandina, S.; Cecilia, M.; Amicucci, G. The effect of sleeve gastrectomy on GLP-1 secretion and gastric emptying: A prospective study. Surg. Obes. Relat. Dis. 2017, 13, 7-14. [CrossRef] [PubMed]

245. Yang, P.-J.; Cheng, M.-F.; Yang, W.-S.; Tsai, M.-S.; Lee, P.-C.; Chen, C.-N.; Lin, M.-T.; Tseng, P.-H. A Higher Preoperative Glycemic Profile Is Associated with Rapid Gastric Emptying After Sleeve Gastrectomy for Obese Subjects. Obes. Surg. 2018, $29,569-578$. [CrossRef] [PubMed]

246. Li, M.; Liu, Y.; Jin, L.; Wang, W.; Zeng, N.; Wang, L.; Zhao, K.; Xu, W.; Zhang, Z.; Yang, J. Alterations of Gastric Emptying Features Following Laparoscopic Sleeve Gastrectomy in Chinese Patients with Obesity: A Self-Controlled Observational Study. Obes. Surg. 2018, 29, 617-625. [CrossRef] [PubMed]

247. Salman, M.A.; Mikhail, H.M.S.; Abdelsalam, A.; Abdallah, A.; Elshafey, H.E.; Abouelregal, T.E.; Omar, M.G.; ElKassar, H.; Ahmed, R.A.; Atallah, M.; et al. Acceleration of Gastric Emptying and Improvement of GERD Outcome After Laparoscopic Sleeve Gastrectomy in Non-diabetic Obese Patients. Obes. Surg. 2020, 30, 2676-2683. [CrossRef] [PubMed]

248. Johari, Y.; Wickremasinghe, A.; Kiswandono, P.; Yue, H.; Ooi, G.; Laurie, C.; Hebbard, G.; Beech, P.; Yap, K.; Brown, W.; et al. Mechanisms of Esophageal and Gastric Transit Following Sleeve Gastrectomy. Obes. Surg. 2021, 31, 725-737. [CrossRef] 
249. Svane, M.S.; Bojsen-Møller, K.N.; Martinussen, C.; Dirksen, C.; Madsen, J.L.; Reitelseder, S.; Holm, L.; Rehfeld, J.F.; Kristiansen, V.B.; van Hall, G.; et al. Postprandial Nutrient Handling and Gastrointestinal Hormone Secretion After Roux-en-Y Gastric Bypass vs Sleeve Gastrectomy. Gastroenterology 2019, 156, 1627-1641. [CrossRef] [PubMed]

250. Dirksen, C.; Damgaard, M.; Bojsen-Møller, K.; Jørgensen, N.; Kielgast, U.; Jacobsen, S.; Naver, L.; Worm, D.; Holst, J.J.; Madsbad, $\mathrm{S}$. Fast pouch emptying, delayed small intestinal transit, and exaggerated gut hormone responses after Roux-en-Y gastric bypass. Neurogastroenterol. Motil. 2013, 25, 346-e255. [CrossRef]

251. Wölnerhanssen, B.K.; Meyer-Gerspach, A.C.; Peters, T.; Beglinger, C.; Peterli, R. Incretin effects, gastric emptying and insulin responses to low oral glucose loads in patients after gastric bypass and lean and obese controls. Surg. Obes. Relat. Dis. 2016, 12, 1320-1327. [CrossRef] [PubMed] 